\title{
A critical review of plant protection tools for reducing pesticide use on grapevine and new perspectives for the implementation of IPM in viticulture
}

\author{
I. Pertot ${ }^{\text {a, }}{ }^{*}$, T. Caffi ${ }^{\text {b }}$, V. Rossi ${ }^{\text {b }}$, L. Mugnai ${ }^{\text {c }}$, C. Hoffmann ${ }^{\text {d }}$, M.S. Grando ${ }^{\text {e }}$, C. Gary ${ }^{\text {, }}$, \\ D. Lafond ${ }^{g}$, C. Duso ${ }^{\text {h}}$, D. Thiery ${ }^{i}$, V. Mazzoni ${ }^{\text {a }}$, G. Anfora ${ }^{\text {a }}$ \\ a Department of Sustainable Agro-Ecosystems and Bioresources, Research and Innovation Centre (FEM), Via E. Mach 1, 38010 S. Michele all'Adige, Italy \\ ${ }^{\mathrm{b}}$ Università Cattolica del Sacro Cuore, DIPROVES - Crop Protection Area, Via Emilia Parmense, 84, Piacenza, Italy \\ ${ }^{\mathrm{c}}$ Università degli Studi di Firenze, Dipartimento di Scienze delle Produzioni Agroalimentari e dell'Ambiente, P.le delle Cascine 28, Firenze, Italy \\ d Julius Kühn-Institute - Federal Research Centre for Cultivated Plants, Institute for Plant Protection in Fruit Crops and Viticulture, Laboratory of Zoology \\ and Integrated Production in Viticulture, Geilweilerhof, 76833 Siebeldingen, Germany \\ e Department of Genomics and Biology of Fruit Crop, Research and Innovation Centre (FEM), Via E. Mach 1, 38010 S. Michele all'Adige, Italy \\ ${ }^{\mathrm{f}}$ INRA, UMR SYSTEM, 34060 Montpellier, France \\ ${ }^{g}$ Institut Français de la Vigne et du Vin - Pôle Val de Loire - Centre, 42 Rue Georges Morel Beaucouze, France \\ ${ }^{\mathrm{h}}$ Università degli studi di Padova, Dipartimento di Agronomia Animali Alimenti Risorse Naturali e Ambiente, Viale dell'università, 16, Legnaro, Italy \\ i INRA, UMR 1065 Santé Agroecologie du Vignoble, ISVV, BP81, 33883 Villenave d'Ornon Cedex, France
}

\section{A R T I C L E I N F O}

\section{Article history:}

Received 31 July 2016

Received in revised form

19 November 2016

Accepted 19 November 2016

Available online $\mathrm{xxx}$

\section{Keywords:}

Integrated pest management

Fungicide

Herbicide

Insecticides

\begin{abstract}
A B S T R A C T
Several pests and diseases have grapevine as their favourite host and the vineyard as preferred environment, so an intensive pesticide schedule is usually required to meet qualitative and quantitative production standards. The need to prevent the negative impact of synthetic chemical pesticides on human health and the environment and the consumer expectations in term of chemical residues in food stimulated the research of innovative tools and methods for sustainable pest management. The research project PURE (www.pure-ipm.eu) was a Europe-wide framework, which demonstrated that several solutions are now available for the growers and evaluated several new alternatives that are under development or almost ready for being applied in practice. Although the use of resistant/tolerant varieties is not yet feasible in several traditional grape growing areas, at least part of the synthetic chemical pesticides can be substituted with biocontrol agents to control pests and pathogens and/or pheromone mating disruption, or the number of treatments can be reduced by the use of decision support systems, which identify the optimal timing for the applications. This review presents the state of the art and the perspectives in the field of grapevine protection tools and strategies.
\end{abstract}

(c) 2016 Elsevier Ltd. All rights reserved.

\section{Introduction}

Grapevine is one of the most important crops worldwide, in relation to the production of both wine and table grapes. Several pests and diseases may affect grapevine, so an intensive pesticide schedule is often required to meet production standards. Precise quantification of the synthetic chemical pesticides used for the grapevine is not available and the quantities can be highly variable in different years and locations, depending on the relative

\footnotetext{
* Corresponding author.

E-mail address: ilaria.pertot@fmach.it (I. Pertot).
}

importance of each pest and pathogen. In general, fungicides account for the largest share of pesticide treatments in most vineyards (with an average of 12-15, up to 25-30 applications in the most problematic conditions; for example see for Italy http://www. istat.it/it/archivio/15004).

Since their introduction from America in the $19^{\text {th }}$ century Plasmopara viticola (the causal agent of downy mildew) and Erysiphe necator (the causal agent of powdery mildew) represent the most important grapevine diseases, and together with Botrytis cinerea (the causal agent of grey mould) account for the largest number of treatments in vineyards. Another pathogen originating from North America Phyllosticta ampelicida (syn. Guignardia bidwellii), which is the causal agent of black rot, occasionally causes damage, especially 
in vineyards that are pruned and harvested mechanically or located closely to abandoned infested vineyards, because the pathogen overwinters on berry mummies, which may remain on the plants. Phyllosticta ampelicida does not usually require additional treatments, because chemical protection against powdery and downy mildews is sufficient to prevent black rot, although in recent years, especially because of increased use of active ingredients specific against oomycetes and the adoption of downy mildew resistant varieties, its importance is increasing. Other diseases such as cane blight (Phomopsis viticola) and leaf spot or "rotbrenner" (Pseudopezicula tracheiphila) appearing occasionally or in specific geographical locations, do not require an extensive fungicide schedule, but rather better timing of treatments against the main grapevine pathogens (Nita et al., 2006; Reiss and Zinkernagel, 1997).

Grapevine trunk diseases (GTDs) are a recent threat to viticulture sustainability. Wood diseases have always affected tree crops, but their recent spread and the increase in severity worldwide (Mugnai et al., 1999; Bertsch et al., 2013) are probably the result of environmental changes and undoubtedly related to the way we have been growing grapevines in the last century (Surico et al., 2004). Grapevine trunk diseases, which affect the main trunk and cordons, include canker caused by Botryosphaeriaceae or Diatrypaceae fungal pathogens (such as Eutypa dieback) and are becoming increasingly important, along with black foot disease (caused by Dactylonectria and Ilyonectria species), which typically affects the roots and collars of young vines. The most common and damaging GTD in Europe is a complex of diseases - the esca complex - involving vascular fungal pathogens, decay agents and their likely interaction with canker pathogens. It is worth mentioning that interaction between multiple pathogens, including their virulence factors (indeed many of them produce active phytotoxins), and the physiological status of the plant in GTDs is crucial for the development of the disease (Fontaine et al., 2016).

Pesticide use against grape arthropods is usually low to moderate (1-4 insecticide applications per year), except for table grape production (up to 8-10 insecticide applications per year). Insecticide overuse is often associated with toxicological and environmental problems, and neurotoxic insecticides or insect growth regulators in particular are suspected of causing human diseases (Fantke et al., 2012). As a consequence, such products have been banned in the European Union (Karabelas et al., 2009). Resistance to insecticides and acaricides is a major concern, although in viticulture this problem was more frequent for fungicides. Pest resurgence and pesticide-induced pests have represented additional implications of insecticide use in viticulture (McMurtry et al., 1970; Duso et al., 2012). Spider mite (in particular Tetranychus urticae and Panonychus ulmi) outbreaks after the Second World War have been claimed to be a consequence of insecticide use (e.g. chlorinates, organophosphates and carbamates), and recent problems with scales (e.g. Parthenolecanium corni) are considered to be another example of this phenomenon. The occurrence of new pests is another concern for European viticulturists. In the last 15 years, two leafminers (Phyllocnistis vitegenella and Antispila oinophylla) and a leafhopper (Erasmoneura vulnerata) have been detected in northern Italy. Recent findings suggest that the impact of some pests will increase with increasing temperatures (Reineke and Thiéry, 2016).

Problems associated with old synthetic chemical pesticides and consumer demand for residue free products have stimulated research into new tools for pest management. Chemical companies are developing new active substances with a favourable profile for human health and the environment, and new mechanism of action with lower risk of developing resistant pest populations. Alternatives to synthetic chemical pesticides are represented by a number of microbial and botanical active ingredients and pheromonebased tactics in the case of insecticides alone. Inoculative and inundative biocontrol techniques (e.g. release of predators or parasitoids commercially produced by biofactories) against insect pests have been less investigated in vineyards than in other agricultural systems such as greenhouse vegetables and ornamental plants. In contrast, conservation biocontrol strategies have attracted the interest of researchers in order to successfully manage various pests, mainly grape berry moths and leafhoppers.

A drastic change in the grapevine cropping system (for example the use of insect proof nets or plastic covers and tunnels along the rows, etc.) is unlikely to happen in Europe, for economic (e.g. traditional varieties are used for the production of most of the more profitable wines) and environmental reasons (e.g. high visual negative impact on the traditional landscape). Therefore, the growers should combine several different tools in order to reduce the input of synthetic chemical pesticides on this crop. Agronomic practices, i.e. reduction of the inoculum or improvement of the microclimate of the plant in order to avoid conditions favourable to pests and diseases, are commonly implemented in most of the grape growing areas. Resistant/tolerant varieties may represent a solution to reduce fungicide treatments, however their implementation is widely limited by the market, especially for wines produced in typical areas (e.g. AOC in France, DOC and DOCG in Italy). Biopesticides based on microorganisms or natural molecules may represent an alternative to synthetic chemicals, however several of existing solutions have drawbacks or limiting factors, which prevent a fast uptake by the farmers (Lamichhane et al., 2016). On the contrary, beneficial arthropods and the use of semiochemicals may offer interesting and sustainable alternatives to synthetic chemical pesticides in certain contexts. Due to all these reasons, the correct timing of the synthetic chemical application is still a crucial step to achieve a sustainable use of pesticides.

Differently from annual crops and other perennial fruit crops, in most of the traditional growing areas grape production cannot benefit from crop rotation or a radical change of the cropping system. Therefore the IPM toolbox includes: the use, wherever possible, of resistant/tolerant varieties, the substitution of the synthetic chemical pesticides with biocontrol agents against pathogens, arthropod pests and disease vectors and/or the use of semiochemicals and physical mating disruption. When substitution with alternatives is not possible, mathematical models and monitoring can help in optimising the pesticide applications. The alternatives to herbicide use are cover cropping and tillage.

\section{Possible solutions offered by resistant/tolerant varieties}

\subsection{Downy and powdery mildew resistant/tolerant Vitis hybrids or varieties}

Since the end of the $19^{\text {th }}$ century, after the introduction of $P$. viticola and E. necator from America to Europe, growing traditional Vitis vinifera varieties has no longer been possible without considerable fungicide applications. Initial efforts in Alsace (France) to breed new disease-resistant varieties by crossing resistant American Vitis species with traditional European $V$. vinifera led to fairly resistant hybrids, which, however, often produced an undesired off-flavour in wine (foxy taint). According to Töpfer et al. (2011), planting of such hybrids in large areas led to a decrease in wine quality in those areas. Thus, consumers often associate resistant varieties with off-flavours and poor wine quality. A small number of breeding programmes in Europe have continued crossing hybrids with $V$. vinifera varieties in order to obtain resistant varieties with the traditional flavours that consumers are used to. Breeding techniques have evolved radically over time (Töpfer et al., 
2011) and the new breeding techniques (i.e. marker assisted selection, gene mapping, in vitro-culture and genetic engineering and pyramiding of resistance, etc.) have become more and more important in recent years. Because of these efforts, several new resistant varieties are or will soon become available (www. bundessortenamt.de). Most of them are still mostly unknown to consumers. Because these genotypes only require a minimal fungicide-spraying schedule compared to traditional varieties, their cultivation has the potential to markedly reduce overall spraying in viticulture. However, plant protection is closely related to local agronomic and weather conditions, and the level of resistance is specific to the genotype and the pathogen's inoculum, therefore the extent of fungicide reduction that could be achieved by growing these resistant varieties has not yet been precisely estimated. Germany is the country with the highest number of licensed mildew resistant grape varieties, listed in a database of the federal Bundessortenamt (www.bundessortenamt.de). Resistant varieties may vary enormously with regard to the level of resistance to the various diseases and wine type and quality. Resistance to downy mildew or powdery mildew has been described for different varieties, as well as resistance and susceptibility against $B$. cinerea (Alonso-Villaverde et al., 2008). Some varieties have been found to have an acceptable level of resistance against $P$. ampelicida. In a recent European research project, a comprehensive list of grape varieties officially authorised for cultivation was established (Lacombe et al., 2011). Disease resistant wine grape varieties included in this European catalogue are listed in Supplementary Table 1.

The modern techniques used in breeding programmes are also useful for understanding the nature, level and durability of resistance (Töpfer et al., 2011). Much work has been carried out in the last years to understand the nature or mechanisms of resistance and to find resistance loci within the grape genome. Monogenetic resistance can be overcome by strains of "adapted" and more virulent pathogens, as reported for the downy mildew resistant variety Bianca (Peressotti et al., 2010). Therefore, the current aim in resistance breeding is to pyramidise resistance genes of different origin (i.e. from $V$. rotundifolia and $V$. amurensis) into a single genotype (Töpfer et al., 2011) and to cross them with $V$. vinifera in order to obtain both highly resistant genotypes and varieties for quality wine production. The volatiles leading to the undesired odour of the wine of old hybrid varieties have been identified (Rapp et al., 1980), allowing the selection of genotypes free of such offflavours. The new resistant genotypes can provide wine quality comparable to wines made with $V$. vinifera varieties (Pedneault and Provost, 2016). However, growers and winemakers need to acquire sufficient experience, to optimise both agronomic practices and oenological processing in order to exploit the full potential of these new resistant genotypes.

Resistant genes against $B$. cinerea are not yet known and breeding programs are primarily targeting downy and powdery mildew. However the choice of less susceptible varieties or clones (hard skin, loose bunch, early bearing, etc.) quite often represents the easiest and most effective solution against grey mould.

\subsection{The advantages of growing resistant varieties and bottlenecks for their adoption}

There are several advantages of growing powdery and/or downy mildew resistant grape varieties and they can be summarised as follows:

I protection of the environment by lowering the use of pesticides and fuel by up to $60-100 \%$;
II reduction of production costs and the risk of losses due to diseases;

III lowering of work peaks;

IV less pesticide exposure for workers;

$\mathrm{V}$ less soil compaction because of reduced sprayer movement in vineyards;

VI reduced accumulation of copper residues in soil (in fact copper is still used, both as single active ingredient against $P$. viticola or in combination with other synthetic chemical fungicides to prevent pathogen's resistance built-up);

VII enhancement of biodiversity within vineyards, as there are fewer adverse effects on flora and fauna.

Several bottlenecks have been identified to explain the limited adoption of resistant varieties by growers (Pedneault and Provost, 2016). The new varieties often have different growing requirements, thus agronomic practices need to be adapted. A lack of oenological experience with the new varieties might lead to low wine quality and related scarce acceptance by consumers, thus discouraging their use. Besides difficulties in market acceptance, there are often legal problems in many countries, where growing resistant varieties for wine production is not yet allowed.

\subsection{Outlook for the future of resistant varieties}

The future wine industry is expected to benefit from exploration of new genetic diversity through both traditional and precision breeding. Several molecular tools are available to help breeders introgress desirable traits from wild relatives into new grape varieties. In addition, the recent advent of genome-editing technologies offers unprecedented opportunities for improving stress resistance in existing elite varieties. Genomic investigations indicate that backcrossing with $V$. vinifera was not extensively used in conventional hybridisation in the past, suggesting that grape breeding has yet to fully exploit the potential of combining key traits from wild species into new varieties with a high $V$. vinifera content (Migicovsky et al., 2016). Marker-assisted development of resistant varieties with desirable $V$. vinifera ancestry could eventually lead to increased acceptance of hybrid grapes by winemakers and relaxation of regulations against their planting. Multiple resistance gene introgression into a single variety, a process called pyramiding, could also include resilience factors reacquired from the European wild ancestor of the cultivated grapevine, unintentionally lost during domestication (Duan et al., 2016). MrRUN1 and MrRPV1 are the first resistance genes (against powdery and downy mildew, respectively) from the grapevine to be cloned and functionally characterised. Feechan et al. (2013) have shown that these resistance genes can be transferred from a wild grapevine species to premium $V$. vinifera varieties through genetic modification, and confer strong resistance against the two major pathogens of cultivated grapevines worldwide. The high level of synteny between the wild North American species Muscadinia rotundifolia and the European cultivated grapevine at the MrRUN1/MrRPV1 locus also opens up the possibility of obtaining resistant phenotypes from elite varieties using targeted genome engineering. Alternative approaches to R-genes may be based on susceptibility genes (Sgenes), in which loss of function results in recessively inherited resistance (Pessina et al., 2016). In any event, with the increase in the acreage of partially resistant varieties grown, the evolution of pathogen populations responding to new host plant selective pressure will require further monitoring (Delmotte et al., 2014). In conclusion, new resilient or resistant cultivars should be considered important tools to be integrated in the IPM framework, rather than a stand-alone solution (Lamichhane et al., 2015). 


\section{Biocontrol agents against pathogens}

\subsection{Leaf and bunch disease}

To prevent a disease it is possible to intervene on one or all of the factors responsible for its development: the pathogen, the plant and the environmental conditions. Although the role of microbial consortia residing inside and outside plant tissues should be considered another important factor in the development of diseases (Lamichhane and Venturi, 2015), limited knowledge is available on how to practically manipulate microbial plant communities on/in the grapevine in order to prevent diseases. Preventive actions for the pathogen are linked to reduction of the inoculum and the planting of healthy nursery material. In relation to the plant, growers can use resistant or less susceptible varieties, clones and rootstock, while actions related to the environment mainly concern plant architecture (trellis and training systems) and a reduction in plant vigour, which can partially modify the microclimate, making it less favourable for the development of the pathogen. However, although theoretically these actions can substantially reduce the risk of disease, in practice quite often technical, economic and commercial barriers strongly reduce their feasibility.

The approach used to combat most of the plant pathogens is commonly different from that used against insect and mites, where treatments are often applied when an economic threshold is reached. Indeed, for reaching a satisfactory pest control level, natural enemies are in most cases sufficient (Duso and Vettorazzo, 1999). In contrast, keeping the level of the inoculum of plant pathogens low is crucial. This is why in the last few years researchers have focused on techniques that can minimise the overwintering inoculum or on optimal control of primary infections and/or the initial stages of an epidemic (Caffi et al., 2013a,b). Careful disease control in the initial part of the season is also justified by the fact that, at least for powdery and downy mildew, the most susceptible stages are between blooming and the stage in which the young berries become resistant (ontogenic resistance). Ontogenic resistance occurs when the stomata on rachis loose functionality and approximately three weeks after bloom, for downy and powdery mildew, respectively (Gadoury et al., 2003; Gindro et al., 2012).

Reducing the inoculum is particularly effective for pathogens such as Ph. viticola and $P$. ampelicida, which overwinter on infected shoots or mummified berries, respectively. The reduction in the inoculum of soil-borne pathogens (i.e. Armillaria mellea, Rosellinia necatrix), with one or more years of alternation with non-host crops, is the only measure available against these rare, but very important root pathogens (Pertot et al., 2008). On the other hand, reducing the inoculum of pathogens such as $B$. cinerea or the consortium of microorganisms causing sour rot in berries is impractical, because of the wide range of substrates (decaying material in/ on soil, dead grapevine berries and leaves, flower residues, other hosts, etc.) that can be colonised by these microorganisms in the vineyard. Instead of focusing on inoculum reduction, for these diseases the prevention of damage to fruit, the right choice of variety/clone, vineyard exposure and plant architecture are more crucial to reduce the risk of infections. In fact winter pruning, trimming and leaf removal in the fruiting zone at the "pea-size berries" stage can favour air movement in the canopy and bunch exposure to sunlight, with a direct (e.g. making berry skin thicker or resistant) and indirect effect (e.g. microclimate unsuitable for infections) against diseases such as grey mould, powdery and downy mildew (Gubler et al., 1987). The interest in planting resistant varieties is slowly, but constantly increasing in viticulture, however, they should not be used as a stand-alone technique, but rather integrated within the frame of IPM.

Although the correct agronomic practices and the use of less susceptible varieties are undoubtedly important pillars in the protection of grapevine against pathogens, direct control of the pathogens with fungicides is normally needed in all grape growing areas. An alternative to synthetic chemical fungicides is represented by biofungicides, where the active ingredient is a microorganism (or its derivate) or a botanical extract (botanicals). In contrast to US legislation, the European Union does not distinguish between the synthetic or natural origin of active ingredients, which follow the same rules in the registration process [Regulation (EC) $1107 / 2009]$. However, biopesticides are more likely to be approved as "low risk substances" when complying with the criteria listed in the regulation.

The number of microorganisms and botanicals tested so far against the three main grapevine pathogens is very large (Dagostin et al., 2011; Gadoury et al., 2012; Jacometti et al., 2010). Unfortunately, most of them have not yet been developed as commercial biofungicides, for reasons, such as their poor survival in the phyllosphere or carphosphere, short shelf-life, the production of secondary metabolites of concern for the human health and the environment, high costs for industrial production or formulation, etc. At the time this review was written, commercial biofungicides tested or registered against grapevine diseases belonged to species of Bacillus subtilis, B. amyloliquefaciens, Ampelomyces quisqualis, Aureobasidium pullulans and several species of the Trichoderma genus (i.e. T. asperellum, T. atroviride, T. gamsii, T. harzianum). Except for A. quisqualis, which is a specific hyperparasite of powdery mildews, the other microorganisms are authorised in Europe for use against $B$. cinerea, or in the case of Trichoderma species, against wood diseases (http://ec.europa.eu/food/plant/pesticides/eupesticides-database/public/).

Although very complex and diverse, and coexisting most of the time in the same microorganism, the mechanisms of action of the microbial biocontrol agents (Benítez et al., 2004) contained in biofungicides can be grouped into those associated with:

I antibiosis (production of enzymes and/or antibiotic metabolites, including volatile organic compounds);

II induction of systemic resistance in the plant;

III hyperparasitism;

IV competition for space and nutrients.

In spite of major research efforts in the last few decades, no satisfactory alternatives to synthetic chemicals and copper have been found against $P$. viticola (Dagostin et al., 2011). The reason for this failure can be found in the nature of the pathogen and the conditions in which infection occurs. Indeed, $P$. viticola penetrates tissues through the stomata very rapidly and, without a highly effective preventive substance, after penetration only systemic active ingredients can partially stop the disease. In addition, a single infection can destroy a young bunch, resulting in high losses. In periods of frequent rain, when secondary infections may occur almost daily, biofungicides, in contrast to systemic chemicals, may be insufficient to control the disease, because they are easily washed off by precipitation and have low persistence.

More options are available against powdery mildew. For example, potassium bicarbonate represents a practicable alternative to synthetic chemical fungicides or sulphur (Crisp et al., 2006), although it is commonly less effective than these ones. Other examples are plant extracts and seaweed (laminarin), COS-OGA, chitin or chitosan mainly act by inducing systemic resistance in the plant (Iriti et al., 2011; van Aubel et al., 2014; Vera et al., 2011). These compounds are indeed recognised as "alarm signals" by the plant, which reacts with the activation of specific self-protection 
pathways (mediated by salicylic acid and/or by jasmonic acid/ ethylene). On grapevines, induced resistance can result in partial control of E. necator, especially if used with low disease pressure.

Being a hyperparasite, $A$. quisqualis needs the presence of some pathogens and can only be applied when the temperature is not too high, if possible with high relative humidity, which makes this biofungicide often unsuitable for spring-summer application. In contrast, A. quisqualis can be a useful tool for reducing the overwintering inoculum of $E$. necator, when applied at the time of chasmothecia formation. Indeed, a lower level of overwintering inoculum may result in delayed and weaker primary infection in the following season (Caffi et al., 2013a,b).

Several biofungicides are available against grey mould, and if combined with leaf removal around bunches and other agronomic practices, they can control the disease at a level comparable to synthetic chemical fungicides. Except for the Bacillus species, which has a more direct mechanism of action, the A. pullulans and Trichoderma species act by competing for space and nutrients, either in flower residues trapped inside the bunch after bunch closure or in wounds and cracks that may occur on ripening berries (Elmer and Reglinski, 2006).

Environmental conditions should be taken into consideration at the time of application of all microbial biofungicides. Being living organisms, they can be killed by temperatures that are too high or low, desiccation and UV light (Elmer and Reglinski, 2006). For these reasons, application in the evening or during periods with mild temperature is recommended for most of them. An adequate concentration and evenness of spraying are other important factors that should be taken into consideration when using biofungicides. None of the registered biofungicides registered for grapes interfere with fermentation, therefore treatments very close to harvest are possible. This characteristic makes them particularly suitable for the prevention of $B$. cinerea late in the season.

Biofungicides have several advantages over synthetic chemicals (Table 1). Some of the advantages become also limiting factors. For example the absence of toxicity for humans and the environment and their fast degradation, make their impact on the ecosystem relatively limited. On the other hand, fast degradation also means short persistency and lower efficacy, unless very frequently reapplied. Several other constraints partially limit their wide adoption by growers. Although the cost for their development and registration is lower than for a synthetic chemical, the biofungicide market is growing more slowly than expected. Besides the intrinsic limitations (Table 1), there are several reasons for this slow growth (Lamichhane et al., 2016), for example competition with chemicals, which often represents a very effective solution at lower costs; the unattractive market size for companies, especially for more specific products; the high cost of registration and the related uncertainty of the time required to reach the market; the conservative views of many growers, who trust natural active ingredients less; the lack of willingness to invest in a sector with uncertain development; the poor appeal of applied research and development on this subject for scientists. Nevertheless, there is a growing demand for biological alternatives to chemical fungicides and new more effective solutions could substantially improve disease management in viticulture.

In recent years, the importance of the plant microbiome, the interactions among microorganisms and the potential role of endophytes in disease development and/or control was postulated (Pinto et al., 2014; Lamichhane and Venturi, 2015; Gimenez et al., 2007). Endophytes are microorganisms living, at least a part of their life cycle, within plant tissues without causing disease (Hardoim et al., 2015). In the grapevine they respond to plant physiology and the environment, including the cropping system, and they may play a role in plant resilience or as source of producers of bioactive metabolites (Pancher et al., 2012; Campisano et al., 2014, 2015). Although at the moment the employment of the grapevine microbiome is at its real infancy, great promises are posed in the use of the most advanced technologies for the discovery of the next generation of microbial biofungicides, as for example new microbial antagonists of pathogens, bioactive compounds produced by endophytes or approaches to improve the efficacy of the biocontrol microorganisms (Massart et al., 2015).

\subsection{Grapevine trunk diseases}

Control of GTDs is a clear example of the need for an integrated management approach. In fact research (Mugnai et al., 1999; Bertsch et al., 2013) demonstrated the important role of both nursery (Surico et al., 2004) and vineyard management in the infection and symptom development. For example, training systems and pruning techniques not only create infection courts for pathogens, but also favour dysfunctions in water flow in the vine (Lecomte et al., 2012). Indeed, water flow impairment, interacting primarily, but not exclusively, with pathogen virulence factors (i.e. phytotoxins), leads to a decrease in photosynthesis activity (Fontaine et al., 2016) and finally to vine decline, loss of production and vine death.

Preventing infections in mother vines in the nurseries starts with careful management of mother blocks, even if few tools or protocols with specific efficacy against GTDs agents have been set up. Good hygiene measures and prevention of the infections occurring whenever canes are wounded and cut are the most important and effective practices in the nursery. Recognising the critical importance of these two factors raises the issue of a possible redesign of the entire nursery production process (Gramaje and Armengol, 2011; Gramaje and Di Marco, 2015; Waite et al., 2015). Available tools ready to be applied in the nursery include primarily the use of microbial biofungicides, in particular several Trichoderma species, which have already proved to be efficient against some of the main pathogens associated with GTDs (Fourie and Halleen, 2006; Pertot et al., 2016). In addition, disinfection with hot water treatment has been proposed as a way of reducing infections, albeit with variable results in terms of efficacy and plant quality (Gramaje and Armengol, 2011). On the other hand, additional experimentation is needed to validate the feasibility and efficacy of new technologies and approaches such as the use of ozone (Pierron et al., 2015) and a range of sanitisation products (Gramaje and Di Marco, 2015).

A preventive approach in the vineyard is also highly recommended. Protection against infection needs to start at a very early stage, well before symptoms appear. While this concept is easy to understand, at the same time it is hard for growers to integrate treatment into their application schedules well before the disease symptoms appear. The integrated approach against GTDs must involve all the factors that trigger dysfunction in water transport and plant resilience, including soil management, pruning, training and nutrition. As a preventive measure in vineyards, protection of pruning wound is an essential step, and biological fungicides (mainly based on strains of Trichoderma spp.) are available (Pertot et al., 2016; Zanzotto and Morroni, 2016). Trials are underway with wound protectants containing synthetic pesticides or physical barriers, which may offer additional tools in the near future (Rolshausen et al., 2010).

Regarding approaches aimed at reducing symptoms in the field, the direct effect of nutrition and defence-inducing factors on grapevine leaf stripe disease (esca complex) was proved using foliar applications with minerals and sea weed extracts (Calzarano et al., 2014) or defence inducers such as fosetyl-Al (Di Marco et al., 2011a). Field applications of pesticides known to reduce foliar symptoms 
Table 1

Advantages and limitations linked to the use of microbial biofungicides.

\begin{tabular}{|c|c|}
\hline Advantages & Limitations \\
\hline They do not leave residues on berries & They have low persistency \\
\hline They can be applied close to harvest & If not correctly applied their efficacy can be lower than chemicals \\
\hline They do not interfere with fermentation & Their application needs more care (weather conditions, quality of water, etc.) \\
\hline They are not (or less) toxic for humans and environment & In the case of high disease pressure they can be less effective \\
\hline They are biodegradable & Their effect is often slower than chemicals \\
\hline They are renewable & They are generally more expensive than chemicals \\
\hline Their mechanism of action is complex and can be used in anti-resistance strategies & They cannot be tank-mixed with fungicides (with a few exceptions) \\
\hline They are a useful tool in organic production and integrated pest management & Shelf-life is shorter than for chemicals \\
\hline They are safe for workers & They have a strict expiry date \\
\hline There is no (or a short) re-entry time after spraying & Some of them need to be stored at low temperature \\
\hline They are not phytotoxic & Once open the box/bag should be re-sealed hermetically to prevent humidity \\
\hline They can be applied with a normal atomizer & The suspension, once prepared, cannot be stored for a long time \\
\hline
\end{tabular}

are also under evaluation for botryosphaeria dieback symptoms. Targeted nutrition and induction of plant resistance in order to reduce symptoms and losses when preventive protection has failed should be further explored. In this case, the final aim would be to reduce mortality and maintain productivity in existing GTDsaffected vineyards. Once the wood is already infected, another possible approach to be further explored is to interact with the activity of wood colonising pathogens and their virulence factors. This calls for new products or treatment methods to be applied directly to the wood, mimicking the mechanism activated by winter spraying of the carcinogen sodium arsenite (as recently proposed with formulations based on copper and coformulants by Di Marco et al., 2011b). On heavily affected plants there are also "emergency" approaches, such as trunk renewal, trunk surgery, re-grafting and "curettage", which are invasive, but often useful for prolonging the productivity of the vineyard (Sosnowski et al., 2011; Smart, 2015).

\section{Biocontrol agents against grape insect pests and disease vectors}

\subsection{Microbial biocontrol agents and active ingredients of natural origin}

Among arthropod pests of grapevines in Europe, grape berry moths Lobesia botrana and Eupoecilia ambiguella are of economic importance in most areas. Additionally, Sparganothis pilleriana is currently limited to specific areas. The first species is invasive and recently colonised Californian vineyards (Gilligan et al., 2011), causing major damage to Napa valley production. A number of leafhoppers (e.g. Empoasca vitis and Scaphoideus titanus), scales (e.g. Parthenolecanium corni and Planococcus ficus) and spider mites (e.g. P. ulmi and Eotetranychus carpini) are locally important. Grape tortricid pests are key pests in Europe due to the direct and indirect damage they cause (e.g. the spread of $B$. cinerea and $P$. ampelicida) and can require appropriate control measures, represented by the use of broad-spectrum insecticides (e.g. organophosphates, carbamates and pyrethroids). The latter have frequently been associated with toxicological, environmental and technical problems (e.g. outbreaks of spider mites and minor pests). These issues have promoted the search for alternatives with a reduced risk, such as microbial and botanical pesticides.

Bacillus thuringiensis (Bt) is a well-known microbial biocontrol agent of berry moths. In European vineyards it was the subject of experiments and subsequently field applications in the 1970s. However, its use did not become popular, probably due to contrasting results in terms of efficacy. The limited pest spectrum of Bt represented another disadvantage compared to organophosphates. More recently, interest in Bt has increased because new formulations characterised by higher efficacy and stability have been highlighted. The efficacy of Bt depends on the strain, formulation (e.g. wettable powder or dust), timing and frequency of application, spray volume, pest population density and cultivar features. A better knowledge of Bt properties has improved its use, as current Bt-based formulates (subsp. kurstaki or aizawai) have an efficacy comparable to that of synthetic pesticides in controlling L. botrana (Shahini et al., 2010). Ifoulis and Savopoulou-Soultani (2004) compared dust or wettable powder Bt formulates on 11 grapevine varieties. Both formulates reduced berry moth damage significantly compared to the untreated control, and dust formulate was more effective in most varieties (especially those with loose, average and dense berry cluster compactness). In other trials the possibility of including Bt in pest control strategies aimed at reducing residue levels has been explored, obtaining positive results (Vassiliou, 2011). The potential of $B$. thuringiensis Cry proteins active against various Lepidoptera (Cry1, Cry2, and Cry9 groups) was evaluated on first instar larvae of $L$. botrana. Of the tested proteins, Cry1la or $\mathrm{Cry} 9 \mathrm{C}$, in combination with Cry1 $\mathrm{Ab}$, proved to be the most promising for controlling this pest (De Escudero et al., 2007). However, the use of Bt is currently limited in viticulture, since the efficiency is related to larval feeding behaviour and thus to temperature (Thiéry, 2011).

The efficacy of different entomophagous fungi, among which Beauveria bassiana, as biocontrol agents against various pests has been the subject of study for a long time, but the possibility of using these microbial agents against grapevine pests has been little explored to date. Early studies (Paillot, 1917) demonstrated the potential of $B$. globullifera or Spicaria farinosa, var. verticilloides. However, most of these fungal biocontrol agents have the disadvantage of being generalists, which makes their use against specific target pests difficult. Recently an experimental strain of $B$. bassiana (ITEM-1559) was employed in field experiments in southern Italy. The application of $B$. bassiana reduced $L$. botrana damage and ochratoxin a contamination (Cozzi et al., 2013). In other experiments carried out in northern Italy the use of $B$. bassiana combined with $B$. thuringiensis slightly increased the efficacy of the latter in berry moth control. Beauveria bassiana showed a significant effect against spider mites and thrips, suggesting possible applications against grapevine pests (Vega et al., 2009). Recently a commercial formulate based on B. bassiana (ATCC 74040 strain) was authorised for the control of thrips and spider mites in Italian vineyards.

Among the pesticides based on microbial metabolites, spinosad proved to be effective in controlling grape berry moths and thrips (Vassiliou, 2011). However, spinosad has been reported to be nonselective towards predatory mites (Duso et al., 2014; Ahmad et al., 2015).

The effect of botanical pesticides on grape berry moths has not been widely investigated, despite increasing interest in these compounds in organic viticulture. Pyrethrins have been used for a 
long time against berry moths and other pests, but their efficacy is questionable and the impact on beneficial organisms is a major concern. Plant molecules with ecdysone like effects could be an alternative to synthetic chemical pesticides for the control of various pests and the grape berry moths. Phytoecdysteroids offer an interesting potential and 20 hydroxyecdysone is antifeedant against $L$. botrana larvae and deter oviposition (Thiéry, 2011). Azadirachtin originating from the neem tree, Azadirachta indica (Sapindales Meliaceae) also induce ecdysone like effects. A commercial formulation of azadirachtin was administered orally to $L$. botrana larvae and the effects included an inability to moult properly and deformities, reduction in fecundity and fertility, especially at high doses. Egg hatching was also significantly reduced (Irigaray et al., 2010). Field applications of azadirachtin (commercial product Oikos) against berry moths reduced damage when compared to the untreated control. At the same time, azadirachtin proved to be relatively harmless towards beneficial organisms (e.g. predatory mites). Among the remaining nonsynthetic chemical products, recent investigations have suggested that kaolin has an effect on L. botrana eggs and larvae. At the same time, this mineral product proved to be substantially selective towards $L$. botrana egg parasitoids (Pease et al., 2016).

\subsection{Beneficial arthropods}

There are numerous beneficial macroorganisms (i.e. insects, mites, birds, bats) efficiently acting as predators or parasitoids, which have long been known as natural enemies of viticulture pests. As already noted previously, despite the large amounts of fungicides and insecticides used over decades, the vineyard is far from being a "no parasitoid's land" (Marchesini and Dalla Montà, 1994; Barbaro et al., 2016; see Thiéry, 2011; for a review). Biological control in vineyards is now promising, but is still a challenging issue, with viticulture still suffering from a lack of basic and applied studies. Different biological control approaches, such as conservation, augmentation or dissemination of natural enemies, have been identified as potential levers in controlling vineyard pests and vectors in the next 50 years (Thiéry, 2011). Biological control against insect pests or vectors can be achieved either by natural populations of predators or parasitoids (Thiéry et al., 2001; Rusch et al., 2015), but also by releasing natural enemies.

\subsubsection{Natural control and pest regulation as an ecosystem service}

The natural control of grape berry moths has been studied in past literature, but developments in the field of IPM and agroecology in viticulture is currently stimulating new perspectives (Vincent et al., 2012; Rusch et al., 2016a). These recent works demonstrate that regulation processes can be understood at different spatial levels (from the vineyard to the landscape) according to the biocontrol agents' range of activity (Rusch et al., 2016b) and that inter-row vegetation, especially floral, provides shelter and plant-provided food (Wäckers et al., 2005), enhancing natural control by entomophagous insects (Genini, 2000).

Several insect predators have been identified and besides lacewings and earwigs, other groups are now receiving considerable attention (e.g. Opiliones, Salticids and Carabids) (Rusch et al., 2016b). However, their behaviour has not been sufficiently studied to evaluate their efficiency in different crop conditions.

Larval parasitoids appear to be promising agents for biological control (Moreau et al., 2010). Their occurrence has been reviewed in several works (Marchesini and Dalla Montà, 1994; Thiéry et al., 2001; Thiéry, 2011). Good candidates were identified and some of them may be very efficient in Europe. The ichneumonid Campoplex capitator is certainly the most efficient, and the parasitism rate on berry moths reached $50-80 \%$ in different vineyards. C. capitator forages for hosts over large spatial ranges (Xuéreb and Thiéry, 2006) and diapauses in its host, thus proving active against the first berry moth generation. Among Hymenoptera, two Pteromalids (Dibrachys cavus and afinis) are also interesting parasitoids of pupae (Chuche et al., 2006), especially in winter. Since they are gregarious ectoparasites (several larvae predate the larval host externally), they are easy and cheap to rear in stock cultures and could represent a possibility for biological control. Another interesting species carrying out an important biocontrol activity against berry moths is the tachinid Phytomyptera nigrina.

The use of predatory mites belonging to the Phytoseiidae family against phytophagous mites is probably the most successful case study of biological control in European vineyards (Duso et al., 2012). More than 20 predatory mite species can colonise European vineyards (Tixier et al., 2013) but Typhlodromus pyri and Kampimodromus aberrans proved to be the most effective. Among the less frequent species, $A$. andersoni has received some attention because of its role in spider mite control in orchards and resistance to pesticides (Duso et al., 1992). However, its colonisation is strongly affected by high humidity rates and the spread of downy mildew, which is an alternative food for this species (Duso et al., 2003; Pozzebon and Duso, 2008). The releases of Amblyseius andersoni sometimes fail, most probably because the above mentioned conditions are not met. T. exhilaratus is widespread in central and southern Italy, probably because of its tolerance to low relative humidity and some pesticides (Liguori and Guidi, 1995). The colonisation and performance of T. pyri is strongly influenced by high summer temperature and low relative humidity, the leaf surfaces of certain varieties and the presence of macropredators, while longterm experiments highlighted the high competitiveness of K. aberrans (Duso and Vettorazzo, 1999). This predatory mite species can survive and reproduce at low prey densities and this capacity is positively related to its persistence (Ahmad et al., 2015).

\subsubsection{Biological control based on parasitoids or predator augmentation}

Several attempts at releasing Trichogramma species to combat grape berry moths have been made during the last few decades in different European countries, with varying effectiveness. Various species of Trichogramma were used, for example T. brassicae Bezdenko, T. cacoeciae Marchal, T. dendrolimi Matsumura or T. minutum Riley (Hommay et al., 2002; El-Wakeil et al., 2010). However, the effectiveness of the Trichogramma species could be limited by the hot dry summer climate in most vineyards, and also by the fact that grape berry moths lay isolated eggs, egg clustering being optimal for Trichogramma species foraging behaviour. Predators of berry moth eggs and neonate larvae could also be released. The Orius species are very interesting in this context. They are efficient predators of eggs and young larvae and could thus be considered for large scale control programmes in vineyards in the near future.

Large scale experiments with phytoseiids were conducted in the 1980 s and 1990s in Italian, French and Swiss vineyards. Three methods for T. pyri release in vineyards are known (Duso et al., 2012): i) transfer of canes colonised by overwintered predatory mites during the winter; ii) trapping of predatory mites with textile bands placed on canes and trunks of vines during late summer and autumn, and subsequent transfer of the bands to other plants during winter, and iii) transfer of shoots that have been colonised by predatory mites during spring and/or summer from one vineyard to another. Similar procedures were used with K. aberrans, but the former was more successful (Duso and Vettorazzo, 1999).

The use of organophosphates insecticides and ethylenebisdithiocarbamate fungicides dramatically affected release experiments. Alternatives to these pesticides were found, with promising implications for the biocontrol of spider mites. Later, 
problems with Flavescence dorée and other pathogens (e.g. cane blight and leaf spot) increased pesticide use and associated sideeffects. Thus detection of pesticide resistant strains of predatory mites was particularly important. A number of $T$. pyri and $K$. aberrans strains able to resist to organophosphates and ethylenebisdithiocarbamates were found and released in large areas, with excellent results in terms of spider mite control and predatory mite persistence (Duso et al., 2012). The natural colonisation of predatory mites has been widely studied in France. Natural or seminatural habitats particularly rich in phytoseiid mites, especially $K$. aberrans, can act as reservoir from which aerial dispersal supported by wind can occur (Tixier et al., 2002). Pesticide use greatly affects the settlement of predatory mites arriving from uncultivated surrounding areas and thus knowledge of their side-effects remains crucial to guarantee the success of biocontrol tactics.

\subsubsection{Factors limiting parasitoid efficiency}

Parasitoid survival and host searching behaviour can be affected by pesticide use, grape training systems and the host defence mechanisms of the host immune system. Noxious effects of pesticides against beneficial organisms (in this case parasitoids and predators) are well-documented (Candolfi et al., 1999; Desneux et al., 2007). The resistance of the grape berry moth larvae to parasitoids, involving an immune system with related so-called encapsulation of the parasitoid egg, was unsuspected until recently (Vogelweith et al., 2016). Analysis of L. botrana and E. ambiguella from field larvae exposed to parasitised vineyards revealed an over-expressed immune system in larvae (Vogelweith et al., 2015), and that grape moth species invest differentially in the immune system and behavioural defence against larval parasitoids (Vogelweith et al., 2016).

The number and availability of hosts is also one of the main traits which can limit parasitoid or predator efficiency, and has been widely documented in the literature. Important populations of natural enemies can only be maintained when sufficiently numerous hosts or prey are available, otherwise they decline rapidly. Parasitoids or predators ensuring efficient regulation would thus appear to be limited in terms of population by their own efficacy. In such cases, alternative resources or optimal landscape architecture would help to maintain parasitoid and predator populations. Studying this spatial shift to look for alternative resources, but also the resistance of hosts against natural enemies, will clearly be a challenge for the coming years.

\section{Use of semiochemicals and physical mating disruption}

As mentioned above, the tortricid moths L. botrana and E. ambiguella are the main insect pests of the grapevine in the Mediterranean area. The development of effective semiochemicalbased control methods to reduce the environmental impact of their management in the last few decades has been therefore valuable (Ioriatti et al., 2011; Ioriatti and Lucchi, 2016).

The vast majority of insect semiochemicals that have been adopted commercially and included in IPM programmes are sex pheromones, used for different purposes, in particular for monitoring and mating disruption (MD). Mating disruption with handapplied multipurpose reservoir dispensers is indeed the most effective and widely applied pheromone-based control technique used against grapevine moths worldwide (Ioriatti and Lucchi, 2016). This strategy essentially relies on permeating the crop with relatively low amounts of synthetic sex pheromone that disrupt intraspecific communication of the target species and thus prevent mating (Sanders, 1997).

In the vineyard, all factors influencing the concentration, homogeneity and atmospheric distribution of synthetic pheromone greatly affect the behavioural mechanisms of MD directed at combating tortricid moths. These factors include plant spacing, training systems, plant canopy, leaf density according to the phenological stage of the vines, and the characteristics and field ageing of dispensers. Indeed, the most appropriate mechanisms for fostering mating disruption are still debated and it is likely that they are largely circumstantial, depending on the specific and variable environmental conditions mentioned above. Population density is another key factor for MD success: above a certain population density, mating is not disrupted, regardless of ambient pheromone concentrations. Therefore, according to the local population density, a variable number of hand-applied high-release dispensers ranging from 250 to 1000 per ha must be installed in vineyards, before the onset of the first seasonal flight of grapevine moths, for MD to be effective. There are several types of reservoir dispensers: twist tie ropes, twin ampoules and membranes. These dispensers should preferably be evenly distributed in the vineyard and should be attached to vine shoots so that they are close to the grape cluster, with the foliage protecting them from direct exposure to sun and high temperatures. In any case, regular release rates, the ability to cover the full flight activity of the target species and affordable costs for growers are prerequisites for reliable commercial MD dispensers (Ioriatti et al., 2004).

Other MD formulations making use of different release devices such as aerosol dispensers, microencapsulated sprayable products and nanofibers are still being developed, validated and/or are in the process of registration (Ioriatti and Lucchi, 2016). Like most pheromone-based methods, MD to combat grapevine moths has also been shown to produce better results when applied in areawide programmes over several years. Examples in different areas have demonstrated that, in these cases, it is possible to reduce or even eliminate the use of insecticides, and consequently to enhance the natural activity of beneficial arthropods and effectively safeguard both environmental and human health. However, sometimes the dramatic reduction in insecticide treatments used against the key pests in an agro-ecosystem is surprisingly one of the main limitations to the extensive use of MD. In fact, in vineyards the outbreaks of resident secondary pests or the invasion of new alien species is facilitated by the reduction in insecticide use as a result of MD application to combat grapevine moths. Therefore, in order to not jeopardize the adoption of MD, it is also crucial to develop environmentally safe control methods against these secondary pests (Ioriatti and Lucchi, 2016).

As an example, MD has been studied and applied to combat the mealybug $P$. ficus, obtaining positive results in terms of reducing mealybug density; moreover, a lower percentage of ovipositing females was detected in the disrupted plots. Furthermore, MD did not negatively affect the parasitism rate. These results would appear to pave the way for setting up new MD multispecies dispensers, containing grapevine moth and mealybug pheromones (Walton et al., 2006; Cocco et al., 2014).

In the last few years, further studies have concentrated on the interaction between host plant volatiles (kairomones) and sex pheromones (Anfora et al., 2009). In particular, it would be of great interest to find synergistic effects, in order to strongly increase the efficacy of the aforementioned techniques and also interfere with female behaviour.

Principles basic to mating disruption by means of pheromones could be applicable to other communication systems as well. Indeed, confusing individuals by releasing false sexual cues into their environment is not necessarily limited to odours. It was recently demonstrated that playback of specific synthetic vibrations into grapevine tissues is effective in preventing the mating of S. titanus pairs both in controlled and open field conditions (Mazzoni et al., 2009a; Eriksson et al., 2012; Polajnar et al., 2015). 
This insect is a leafhopper, accidentally introduced into Europe during the 1950s, and is now widely distributed in the most important European grape-growing areas. Scaphoideus titanus is a significant pest of grapes, quarantined in the European Union since it is a vector of the incurable phytoplasma disease, Flavescence dorée (Chuche and Thiéry, 2014). The mating behaviour of this species is mediated exclusively by substrate-borne vibrational signals (Mazzoni et al., 2009b). These vibrations are speciesspecific, as they are characterised by three main parameters (frequency, intensity and temporal pattern) that combine to characterise the species. Vibrational signals are therefore just as individual as the blend of pheromone molecules. In addition, insects such as $S$. titanus show complex intra-sexual competition between males, also regulated by other specific vibrational signals, called "rivalry" signals. This means that when two males are in the presence of a receptive female, they must face one other in a crude challenge before establishing a proper mating duet. Each male emits his rivalry signal each time the female replies to the other male's courtship song in order to mask it. Since this signal is the only directional cue provided by the female to searching males, by masking it the mating sequence is interrupted (Mazzoni et al., 2009a). Indeed, while in nature one male eventually gives in to the other, the continuous artificial insertion of a calibrated number of rivalry signals into grapevine plants is decisive in preventing mating. Disruptive signals must be well calibrated, because in order to interfere with a species like $S$. titanus, it is necessary to send a disruptive signal that travels through the plants with a certain frequency range $(200-250 \mathrm{~Hz})$ and intensity $\left(10-100 \times 10^{-3} \mathrm{~mm} /\right.$ $\mathrm{s}$, as the speed of substrate vibration) (Eriksson et al., 2012). The disruptive effect could also be obtained using more generic (broadband) signals, such as white noise (Mazzoni et al., 2009a), but the use of such a signal would not contain much of the specificity required for eco-compatible tools, in that it would also be likely to affect target species present in the vineyard and communicating using substrate-borne vibrations, such as predators (e.g. spiders) and parasitoids (Virant-Doberlet et al., 2011; Meyhofer and Casas, 1999). Field tests proved the efficacy of this innovative method by preventing the mating of more than $90 \%$ of $S$. titanus pairs (Eriksson et al., 2012).

\section{Combination of mathematical models and monitoring: from single models to decision support systems}

A plant disease model is a simplification of a real system made up of the pathogen, the host plant and the environment. Models are used in botanical epidemiology in order to describe, understand, predict and compare epidemics and their components (Rossi et al., 2010). A concrete aid for growers is represented by prediction of a disease, where prediction is the process of estimation in unknown past, current or future situations, which is different from forecasting, the latter term being reserved for extrapolations at future times only (Rossi et al., 2010).

Overall, plant disease models can be defined as empirical or analytical, according to the approach followed during their development: they have pros and cons in terms of time, efforts and investments needed for their development, but also in terms of precision and robustness of the output provided (De Wolf and Isard, 2007; Maanen and Xu, 2003; Rossi et al., 2010; Caffi et al., 2007).

With the quality enhancement and computing power offered by computers and laptops, models have been consistently incorporated in decision support systems (DSSs), which are tools that assist users in tactical and operational decision-making in crop protection (Rossi et al., 2012). Models can also be part of disease warning systems at local level (Rossi et al., 2012).

\subsection{Modelling downy mildew}

A strong boost to the development of new models arrived in the last two decades of the $20^{\text {th }}$ century. In France, the EPI model was developed based on the assumption that the presence of $P$. viticola in a vine-growing area is the result of ecological adaptation of the fungus to the climatic conditions of the area and that yearly deviations from the climatic conditions in that area may explain changes in disease development. Tran Manh Sung et al. (1990) developed the POM model to calculate the date when most oospores are mature, and the consequent disease severity in vineyards. Hill developed a predictor for periods of fast oospore germination activity. The DMCAST model used the POM model to predict the date of primary infection, when almost $3 \%$ of oospores are able to germinate and there are suitable conditions for infection (Park et al., 1997). Models have been also developed to simulate the progress of secondary infections caused by $P$. viticola, starting from the moment the first downy mildew lesions are observed in a vineyard, or from prediction of the first seasonal infections using the 3-10 rule or similar rules. These models were developed in Switzerland (Blaise and Gessler, 1992), France (Magnien et al., 1991), Australia (Magarey et al., 2002), Germany (Hill, 1990) and Italy (Orlandini et al., 1993).

The above models have been used to schedule the application of pesticides. Unfortunately, they often fail to predict the real development of epidemics and their practical use is restricted (Vercesi et al., 1999). In particular, empirical models have shown some critical restrictions and limitations being too simple, lacking of robust cause-effect relationships in model equations and requiring corrections and calibrations to adapt to grape-growing areas or environmental conditions different from those used for the model development (Caffi et al., 2007).

All the above cited models were developed on the assumption that oospores cause the first seasonal infection and do not contribute further to epidemic development, which is caused by secondary infections. More recent studies have demonstrated that oospores represent a source of inoculum for $P$. viticola infection throughout the season (Gessler et al., 2003; Gobbin et al., 2006; Rossi et al., 2013) and in some cases, their contribution to the epidemic as a whole is higher than that of secondary infections, due to sporangia. This new conception of the $P$. viticola life cycle was recently incorporated in a mechanistic model for the dynamic simulation of primary infections of $P$. viticola (Rossi et al., 2008), linked to a life-cycle model (Rossi et al., 2009). The model of Rossi et al. (2008) was evaluated in more than 100 vineyards in northern, southern, and insular Italy (from 1995 to 2007) as well as with potted grapevine plants exposed to the inoculum (from 2006 to 2008) (Caffi et al., 2009), and also in the environmental conditions in the province of Quebec, Eastern Canada, by comparing the time of lesion emergence predicted by the model with field observations (Caffi et al., 2011a,b). This model always showed very high accuracy (Caffi et al., 2009) and when used to schedule fungicide application against downy mildew, allowed a reduction from 50 to $66 \%$ in pesticide applications, corresponding to an average saving of 174 and $224 € /$ ha, respectively (Caffi et al., 2010). Finally it was integrated into a DSS named vite.net ${ }^{\circledR}$ (Rossi et al., 2014).

\subsection{Modelling powdery mildew}

Epidemiological studies aimed at modelling powdery mildew on the grapevine are relatively recent in comparison to downy mildew, the first attempts at modelling the development of E. necator being performed in California (Sall, 1980) using the basic Vanderplank's compound interest equation for simulating disease development. Other models were developed in the following two 
decades for simulating the population growth of $E$. necator on V. vinifera "Carignane" over time (Chellemi and Marois, 1992), for timing the first application of fungicides in Germany (Kast, 1997), simulating the minimal conditions for ascospore discharge from chasmothecia (Gadoury and Pearson, 1990) or accounting for both the ascosporic and conidial stages of $E$. necator simultaneously (Thomas et al., 1994). More recently a model coupling temporal and spatial vine growth with the development and spread of powdery mildew at vine stock scale was developed (Calonnec et al., 2008) while Carisse et al. (2009a) developed a risk assessment method based on the relationship between the incidence of powdery mildew on the leaves of different varieties and the cumulative concentration of airborne conidia in the vine production area of Quebec, Canada. An updated version of the OiDiag model, OiDiag2.2, was developed considering the ontogenic resistance of bunches (Kast and Bleyer, 2010), Two fully mechanistic, dynamic models were developed to predict: i) the maturation in the vineyard of E. necator chasmothecia (Legler et al., 2011), which develop at specific maturation rates, depending on air temperature; and ii) ascosporic infection dynamics (Caffi et al., 2011b). The former model can represent a key tool for scheduling sanitation treatments, offering a promising approach to reducing the number of overwintering chasmothecia, i.e. the main source of primary inoculum of E. necator in many grape-growing areas (Caffi et al., 2013a,b). The latter model was validated in different Italian grape-growing conditions and was successfully used to schedule fungicide application against powdery mildew in a real time warning system (Caffi et al., 2012a). The use of the model reduced fungicide applications by 36\% (low-risk programme, saving 56 $€ /$ ha/year) or $75 \%$ (high-risk programme, saving $161 € /$ ha/year). This model was also included in the DSS vite.net ${ }^{\circledR}$ (Rossi et al., 2014).

Finally, a holistic approach to quantitative modelling of the E. necator life cycle was proposed by Legler et al. (2010). This model considers the entire life cycle of the pathogen, offering a global vision of the pathosystem as a dynamic process. This model should facilitate an integrated approach for protecting grapevines against powdery mildew by accounting for all management options, from reducing the overwintering inoculum using sanitation to protection of leaves and bunches during the epidemic (Caffi et al., 2013a,b).

\subsection{Modelling grey mould}

Only a few studies have been carried out to model B. cinerea, the causal agent of grey mould on the grapevine. An empirical rule was proposed by Nelson (1956) and then refined some years later by Bulit et al. (1970) who formulated the "two fifteens rule": an infection by $B$. cinerea may occur when the grapes remain wet for 15 consecutive hours at a temperature of at least $15{ }^{\circ} \mathrm{C}$.

In the following decades only three empirical models were developed for grey mould, two of them expressing infection severity on flowers and/or berries on the basis of wetness duration and temperature, in Australia (Nair and Allen, 1993) and California (Broome et al., 1995). The third model was recently developed in Spain, charting the aerial concentrations of $B$. cinerea spores on the basis of the growth stage of the grapevine (Rodriguez-Rajo et al., 2010).

In the late 1990s an expert system was developed in Australia as a set of "if-then" rules organised in a decision tree made up of three main sections: i) "fungicide coverage" (i.e. the residual presence or absence of a previous treatment); ii) the "economic threshold" (e.g. grapevines for premium quality or bulk wine); and iii) "disease risk" (e.g. due to a combination of different factors such as injury, growth stage, susceptibility, infections and symptoms) (Ellison et al., 1998).

Recently, a DSS was developed in Australia to manage grey mould using weather data, vineyard growth stages and disease management input between flowering and the beginning of ripening, in order to visualise the seasonal risk level for botrytis. The late season botrytis risk model predicts botrytis incidence according to berry sugar accumulation ( ${ }^{\circ} \mathrm{Brix}$ ) between veraison and harvest.

Recently, a new, mechanistic model for $B$. cinerea on the grapevine was developed (Gonzalez et al., 2015), representing an improvement on previous models used in viticulture. The model, which accounts for conidial production on various inoculum sources and for multiple infection pathways, considers two infection periods ("inflorescence clearly visible" to "groat-sized berries", and "the majority of berries touching" to "berries ripe for harvest"). The model calculates the infection severity and classifies the epidemic as mild, intermediate or severe. The model was validated in 21 epidemics (vineyard $\times$ year combinations) between 2009 and 2014 in Italy and France, and correctly classified the severity of 17 out of 21 epidemics. The model can also be used to calculate the daily probability of an ongoing epidemic being mild, intermediate or severe.

\subsection{Scouting}

Scouting was explicitly referred as an IPM tool in relation to grapevine disease at the end of the last century (Oliva et al., 1999) and it represents a key component for IPM implementation according to the Directive 128/2009/EC. Scouting (monitoring) techniques in plant pathology are based on visual assessment of disease symptoms such as severity and/or incidence. Incidence (the percentage of plants, leaves or clusters with disease symptoms) is usually easier to assess with a certain accuracy and a lower risk of overestimation as compared to severity. Disease severity is the percentage of leaf or cluster surface showing disease symptoms. In order to make disease severity assessment easier, specific severity values were described in depth, and diagrams of severity percentages (also known as disease scales) were proposed. A disease scale is usually a graphic representation of selected levels (or classes) of disease severity on a specific organ (i.e. grapevine leaves or bunches). One of the most widely recognised and used scales throughout the world is the severity scale adopted by the European and Mediterranean Plant Protection Organization (www.eppo.int). Disease severity generally correlates better with yield loss than incidence (Lapchin and Shtienberg, 2002), but its assessment in field conditions can be extremely difficult, costly and timeconsuming and may be prone to bias and experimental errors (Guan and Nutter, 2003). For these reasons, a model of the quantitative relationship between incidence and severity could greatly facilitate disease assessment when it is not possible to perform accurate disease monitoring (Seem, 1984). For instance, logistic regression analysis yielded a series of probabilistic models that enabled prediction of pre-set levels of cluster infection risks, based on downy and powdery mildew severity on the foliage at successive crop stages (Savary et al., 2009).

Some disease models require disease monitoring to be initialised, with data such as the date of first disease onset or the severity of initial disease symptoms in the vineyard, but they are difficult to detect (Madden et al., 1995). This initial assessment might be improved by using proper sampling design (Seem et al., 1985). For instance, the part of the vine with highest risk of initial downy mildew lesions is the lower canopy layer, because the probability of impact of rain-generated splashes is higher (Rossi and Caffi, 2012). Similarly, monitoring the basal leaves of shoots closest to the trunk is crucial to identify early powdery mildew 
symptoms, since they are usually observed as small pale yellow spots on the abaxial surfaces of the basal leaves of shoots (Caffi et al., 2011b).

Visual disease monitoring is also a useful tool for disease management in the vineyard for the purpose of scheduling the right treatment and the correct choice of fungicide against $P$. viticola, $E$. necator and $B$. cinerea. Specific image analysis software (e.g. Assess 2.0, Lamari APS Press) can also be used on pictures of affected organs or canopies and represents another useful tool for estimating disease severity on different vegetative organs, e.g. it allows to quantify the size of chlorotic and/or sporulating lesions on grapevine leaves affected by downy mildew (Caffi et al., 2012b).

Nowadays, disease assessment can be complemented by spore sampling (Lapchin and Shtienberg, 2002). Spore sampling protocols were implemented for $P$. viticola sporangia (Kast, 1997) and E. necator conidia (Carisse et al., 2009a). Spore sampling was greatly improved by the use of molecular tools in order to speed up the counting process, as proposed by Carisse et al. (2009b) to develop real-time quantification of the airborne conidia of $B$. cinerea.

\subsection{A step forward: decision support systems}

Decision-support systems are a specific category of computerised information systems supporting decision-making activities. DSSs collect, organise and integrate all types of information required to produce a crop; DSSs then analyse and interpret the information and finally use the analysis to recommend the most appropriate action or action choices. DSSs can potentially include all the requirements for practical implementation of IPM (Rossi et al., 2012).

Today, most of the DSSs available on the market provide the timing for fungicide applications on the basis of one (or more) of the epidemiological models described above, such as VitiMeteo (Bleyer et al., 2011), Agrometeo. ch (Viret et al., 2011), Mildium ${ }^{\circledR}$ (Naud et al., 2010) or EPICure (Raynal et al., 2010). Other DSSs, such as Coptimizer (Kuflik et al., 2009), are specifically aimed at keeping the amount of fungicides below the regulatory threshold, adjusting the copper dose on the basis of the grape growth stage, amount of rainfall and shoot growth. Another group of DSSs were developed with the specific aim of adapting the fungicide dose to the vine canopy characteristics, such as Dosavina (Gil et al., 2011), LAI adapted dosage (Siegfried et al., 2007), and Optidose ${ }^{\circledR}$ (Davy et al., 2010).

Despite their promises, most DSSs have contributed little to practical agriculture (Magarey et al., 2002) because of some limits that slow down a the wider adoption of DSS in viticulture, as: i) their high specificity (e.g. some of them only address one or a few specific problems); ii) the fact that they are sometimes oversimplified, or solve problems that do not concern real-world users; iii) the low quality of the information provided by DSSs due to poor communication between DSS developers and users; iv) lack of a user-friendly interface; v) the time demanded to operate the DSS; vi) the lack of frequent updates on the output provided, as well as the lack of maintenance for the DSS; vii) the lack of widely demonstrated benefits due to the DSS use (Rossi et al., 2014).

A recent example of a DSS dealing with all these limitations is vite.net ${ }^{\circledR}$, an Internet-based platform for sustainable vineyard management (Rossi et al., 2014). In this DSS, the provider interacts closely with the users (viticulturists, advisors, consultants) to: i) design the best monitoring system for each particular situation and then implement the sensor network to monitor the vineyard environment (weather, soil and plants); ii) provide the user with the necessary hand-held devices for scouting the vineyard(s) during the season; and iii) train the user to adopt both the devices and the web-based DSS. The user is only required to enter a few site- specific data for each vineyard into the DSS, and only once. During the season, the DSS analyses vineyard data obtained in real time via GPRS from the sensor network and produces the decisionmaking support; when necessary, the DSS asks the user to scout the vineyard using the hand-held device and send the information. The decision-making support helps the user to make decisions about different management issues, such as multiple pest and disease risk (e.g. downy and powdery mildew, black-rot, grey mould, American leafhoppers, mealybugs and berry moths), the optimal dose of pesticide to be sprayed, the protection provided by the last treatment and the risk of abiotic stress (frost, drought or heat). Being based on the Internet, this DSS allows continuous updating of the entire system, as well as its customisation to user needs. The latter involves feedback from users and the involvement of researchers who have participated during the project, as well as other researchers with specific expertise (Rossi et al., 2012).

As recently demonstrated by Caffi et al. (2014), there is considerable variability in downy mildew epidemics in different areas and years which is closely related to the variability in weather conditions. Moreover, severe epidemics can occur in areas where the disease has not been traditionally considered a key problem. The combination of site-specific weather data, monitoring reports and advice from a DSS enables growers to protect their vineyards by modulating the frequency and timing of fungicide applications, based on disease risk (Caffi et al., 2014).

The DSS vite.net ${ }^{\circledR}$ was tested in 21 organic farms and allowed the reduction of fungicide applications by an average of $24 \%$, with an average saving of $195 € /$ ha/year compared to the usual farm practice (Rossi et al., 2014). During the PURE project (www.pureipm.eu) vite. net ${ }^{\circledR}$ was used from 2012 to 2014 in different conditions, confirming its accuracy in predicting disease risk and its ability to provide useful information to growers: indeed, the use of the DSS allowed growers to calibrate the amount of fungicides applied with any treatment and this resulted in an average reduction in fungicide usage of $31.5 \%$ in IPM and $43.7 \%$ in organic farming, with a consequential reduction in disease management costs of about $200 €$ per hectare per season.

\section{Alternatives to herbicides in viticulture}

\subsection{The alternatives to herbicides}

In viticulture, the alternatives to herbicide use are cover cropping and tillage. These are classic traditional techniques (they were the usual way of managing the soil surface before the invention of herbicides), although herbicides are still used in most vineyards on either part or all of the soil surface. Inter-rows can be covered with either weeds or mono- or pluri-specific stands of annual or perennial herbaceous species. They can be tilled with various types of equipment (such as a mulcher, para-plough, rotating harrow, depth loosener, or grubber etc.). It is possible to alternate cover cropped and tilled inter-rows. Under the rows, specific equipment must be used to maintain the soil surface either bare or covered.

Cover cropping limits runoff and resulting soil erosion and the contamination of surface water by pollutants (pesticide spread and/ or residues in the soil) (Battany and Grismer, 2000; Voltz et al., 2003). Cover cropping increases water infiltration and the storage of "green water" (Gaudin et al., 2010). In winter, it can be used as a catch crop and legumes can be a source of nitrogen. Cover cropping contributes to a better soil structure, and to an increase in the content of organic matter and soil biological activity (Morlat and Jacquet, 2003). Cover cropping improves trafficability in wet conditions (Polge de Combret - Champart et al., 2013). Cover cropping reduces the vegetative vigour of the grapevine and its susceptibility to grey mould (Valdés-Gómez et al., 2008) and downy mildew 
(Valdés-Gómez et al., 2011). Furthermore, because cover cropping competes for soil resources (water, nutrients) with grapevines (Celette et al., 2008, 2009), particularly in dry regions and/or shallow soils, this may generate yield and/or quality losses (e.g. the fermentation of white wines is sensitive to nitrogen deprivation).

Tillage improves soil aeration and water infiltration and eliminates weeds; consequently, the availability of water and nitrogen is higher for the grapevine (Ferrero et al., 2005). Tillage incorporates organic matter in the soil, and stimulates its decomposition. However, tillage favours soil erosion in rainy conditions and in steep-slope vineyards, and it reduces trafficability in wet conditions.

\subsection{Conditions for adopting alternatives to herbicides}

Reducing or eliminating herbicides introduces significant changes to soil surface management policy, particularly in relation to equipment and labour organization. Specific equipment is needed for sowing and maintaining (e.g. mowing) cover crops and for tilling in vineyards. Different equipment is needed for soil surface management in the inter-rows and undervine areas. Steepslope viticulture presents specific difficulties for mechanisation. Maintaining a cover crop or tilling is more costly (specific equipment, more time and energy consumption) than applying herbicides, particularly in undervine areas, where special equipment must be used.

The relative soil surface allotted to cover cropping (for example, every inter-row, one inter-row out of two, etc.) and the type of flora (grass versus legumes, root depth, duration of vegetative cycle) affect the intensity and dynamics of the competition for soil resources with the grapevine. Furthermore, balancing the advantages and disadvantages of cover cropping is difficult in regions with severe summer drought, low availability of soil resources (shallow soils) and high inter-annual rain variability. Only adaptive strategies of soil surface management (e.g. changing with the winter soil water refill) can lead to a stable grape production and provision of ecological services (Ripoche et al., 2011).

Abandoning the use of herbicides is a requirement for shifting to organic viticulture; more generally, the environmentally positive image of reducing herbicide use can be used for marketing purposes. Several initiatives could promote the reduction of herbicide use in Europe:

I Certification of good practices (organic and others);

II Payment of subsidies to growers, conditional on compliance with environmental targets (agri-environmental measures);

III Limitation of the number of registered herbicides available;

IV Design and diffusion of DSSs to optimise soil surface management;

$\mathrm{V}$ Selection of original species for cover cropping, with a low growth rate and low resource demand;

VI Development of biological weed control;

VII Improvement of specific equipment for tilling and/or maintaining cover crops in zero-herbicide strategies.

\section{Conclusion}

Grape-growing has been pioneering in terms of the adoption of several alternatives to synthetic chemical pesticides, and grapes are probably one of the crops where the largest number of tools can be integrated. The combined use of agronomic practices, resistant varieties, biopesticides and mating disruption and optimal use of chemical active substances with the help of DSSs can help to strongly reduce the extent of pesticide application. Further studies and solutions are still needed for nematodes, bacterial, phytoplasma and virus diseases. In addition, new potential challenges in the reduction of pesticide use, which deserve attention of scientists, are the possible invasions of alien species that may require additional treatments and the increase of importance of pests and diseases that are not controlled anymore when highly selective active substances or resistant varieties are used against the major ones.

\section{Acknowledgments}

The authors would like to acknowledge Carmela Sicher for her technical support and assistance. This research was supported by the European Community's Seventh Framework Programme (FP7/ 2007-2013) under grant agreement no.265865- project PURE.

\section{Appendix A. Supplementary data}

Supplementary data related to this article can be found at http:// dx.doi.org/10.1016/j.cropro.2016.11.025.

\section{References}

Ahmad, S., Pozzebon, A., Duso, C., 2015. Predation on heterospecific larvae by adult females of Kampimodromus aberrans, Amblyseius andersoni, Typhlodromus pyri and Phytoseius finitimus (Acari: Phytoseiidae). Exp. Appl. Acarol. 67, 1-20.

Alonso-Villaverde, V., Boso, S., Santiago, J.L., Gago, P., Martinez, M.C., 2008. Relationship between susceptibility to Botrytis bunch rot and grape cluster morphology in the Vitis vinifera L. cultivar Albarino. Int. J. Fruit Sci. 83, 251-265.

Anfora, G., Tasin, M., De Cristofaro, A., Ioriatti, C., Lucchi, A., 2009. Synthetic grape volatiles attract mated Lobesia botrana females in laboratory and field bioassays. J. Chem. Ecol. 35, 1054-1062.

Barbaro, L., Rusch, A., Muirir, E., Gravellier, B., Thiery, D., Castagneyrol, B., 2016 Avian pest control in vineyards is driven by interactions between bird functional diversity and landscape heterogeneity. J. Appl. Ecol. press. http:/ dx.doi.org/10.1111/1365-2664.12740.

Battany, M.C., Grismer, M.E., 2000. Rainfall runoff and erosion in Napa Valley vineyards: effects of slope, cover and surface roughness. Hydrol. Process. 14, 1289-1304.

Benítez, T., Rincón, A.M., Limón, M.C., Codón, A.C., 2004. Biocontrol mechanisms of Trichoderma strains. Int. Microbiol. 7, 249-260.

Bertsch, C., Ramírez-Suero, M., Magnin-Robert, M., Larignon, P., Chong, J., AbouMansour, E., Fontaine, F., 2013. Grapevine trunk diseases: complex and still poorly understood. Plant Pathol. 62, 243-265.

Blaise, P., Gessler, C., 1992. Vinemild: toward a management tool for grape downy mildew. Acta Hortic. 313, 257-262.

Bleyer, G., Kassemeyer, H.H., Breuer, M., Krause, R., Viret, O., Dubuis, P.H. Frabre, A.L., Bloesch, B., Siegfried, W., Naef, A., Huber, M., 2011. "VitiMeteo" a future oriented forecasting system for viticulture. Bull. IOBC/WPRS 67, 69-77.

Broome, J.C., English, J.T., Marois, J.J., Latorre, B.A., Aviles, J.C., 1995. Development of an infection model for Botrytis bunch rot of grapes based on wetness duration and temperature. Phytopathology 85, 97-102.

Bulit, J., Lafon, R., Guillier, G., 1970. Favourable periods for applying treatments for the control of grey mould of vines. Phytiatrie-Phytopharmacie 19, 159-165.

Caffi, T., Legler, S., Rossi, V., 2012a. Evaluation of a warning system for early-season control of grapevine powdery mildew. Plant Dis. 96, 104-110.

Caffi, T., Gilardi, G., Monchiero, M., Rossi, V., 2012b. Production and release of asexual sporangia in Plasmopara viticola. Phytopathology 103, 64-73.

Caffi, T., Legler, S.E., Bugiani, R., Rossi, V., 2013a. Combining sanitation and disease modelling for control of grapevine powdery mildew. Eur. J. Plant Pathol 135, $817-829$.

Caffi, T., Legler, S.E., Bugiani, R., Rossi, V., 2013b. Combining sanitation and disease modelling for control of grapevine powdery mildew. Eur. J. Plant Pathol 135 $817-829$.

Caffi, T., Legler, S., Carotenuto, E., Rossi, V., 2014. Year-to-year weather variability affects downy mildew epidemics in vineyards and should guide decisions regarding fungicide applications. Agrochimica 58, 77-90.

Caffi, T., Rossi, V., Bugiani, R., 2010. Evaluation of a warning system for controlling primary infections of grapevine downy mildew. Plant Dis. 94, 709716.

Caffi, T., Rossi, V., Bugiani, R., Spanna, F., Flamini, L., Cossu, A., Nigro, C., 2009 A model predicting primary infections of Plasmopara viticola in different grapevine-growing areas of Italy. J. Plant Pathol 9, 535-548.

Caffi, T., Rossi, V., Carisse, O., 2011a. Evaluation of a dynamic model for primary infections caused by Plasmopara viticola on grapevine in Quebec. Plant Health Prog. http://dx.doi.org/10.1094/PHP-2011-0126-01-RS.

Caffi, T., Rossi, V., Cossu, A., Fronteddu, F., 2007. Empirical vs. mechanistic models for primary infections of Plasmopara viticola. Bull. IOBC/WPRS 37, 261-271.

Caffi, T., Rossi, V., Legler, S.E., Bugiani, R., 2011b. A mechanistic model simulating ascosporic infections by Erysiphe necator, the powdery mildew fungus of 
grapevine. Plant Pathol. 60, 522-531.

Calonnec, A., Cartolaro, P., Naulin, J.M., Bailey, D., Langlais, M., 2008. A host-pathogen simulation model: powdery mildew of grapevine. Plant Pathol. 57, 493-508.

Calzarano, F., Di Marco, S., D'agostino, V., Schiff, S., Mugnai, L., 2014. Grapevine leaf stripe disease symptoms (esca complex) are reduced by a nutrients and seaweed mixture. Phytopathol. Mediterr. 53, 543-558.

Campisano, A., Antonielli, L., Pancher, M., Yousaf, S., Pindo, M., Pertot, I., 2014 Bacterial endophytic communities in the grapevine depend on pest management. Plos One 9, 11

Campisano, A., Pancher, M., Puopolo, G., Puddu, A., Lopez-Fernandez, S., Biagini, B. Yousaf, S., Pertot, I., 2015. Diversity in endophyte populations reveals functional and taxonomic diversity between wild and domesticated grapevines. Am. J. Enol Vitic. 66, 12-21.

Candolfi, M.P., Bakker, F., Canez, V., Miles, M., Neumann, C., Pilling, E., Primiani, M., Romijn, K., Schmuck, R., Storck-Weyhermüller, S., Ufer, A., Waltersdorfer, A 1999. Sensitivity of non-target arthropods to plant protection products: could Typhlodromus pyri and Aphidius spp. be used as indicator species? Chemosphere 39, 1357-1370.

Carisse, O., Bacona, R., Lefebvre, A., 2009a. Grape powdery mildew (Erysiphe necator) risk assessment based on airborne conidium concentration. Crop Prot. 28 1036-1044.

Carisse, O., Tremblay, D.M., Levesque, C.A., Gindro, K., Ward, P., Houde, A., 2009b. Development of a TaqMan real-time PCR assay for quantification of airborne conidia of Botrytis squamosa and management of Botrytis leaf blight of onion. Phytopathology 99, 1273-1280.

Celette, F., Findeling, A., Gary, C., 2009. Competition for nitrogen in an unfertilized intercropping system: the case of an association of grapevine and grass cover in a Mediterranean climate. Eur. J. Agron. 30, 41-51.

Celette, F., Gaudin, R., Gary, C., 2008. Spatial and temporal changes to the wate regime of a Mediterranean vineyard due to the adoption of cover cropping. Eur. J. Agron. 29, 153-162.

Chellemi, D.O., Marois, J.J., 1992. Development of a demographic model for Uncinula necator by using a microcomputer spreadsheet program. Phytopathology 81 $250-254$.

Chuche, J., Thiéry, D., 2014. Biology and ecology of the flavescence dorée vector Scaphoideus titanus, a review. Agron. Sustain. Dev. 34, 381-403.

Chuche, J., Xuéreb, A., Thiéry, D., 2006. Attraction of Dibrachys cavus (Hymenoptera: pteromalidae) to its host frass volatiles. J. Chem. Ecol. 32, 2721-2731.

Cocco, A., Lentini, A., Serra, G., 2014. Mating disruption of Planococcus ficus (Hemiptera: pseudococcidae) in vineyards using reservoir pheromone dispensers. J. Insect Sci. 144 http://dx.doi.org/10.1093/jisesa/ieu006.

Cozzi, G., Somma, S., Haidukowski, M., Logrieco, A.F., 2013. Ochratoxin A management in vineyards by Lobesia botrana biocontrol. Toxins 5, 49-59.

Crisp, P., Wicks, T.J., Bruer, D., Scott, E.S., 2006. An evaluation of biological and abiotic controls for grapevine powdery mildew. 2. Vineyard trials. Aust. J. Grape Wine Res. 12, 203-211.

Dagostin, S., Schaerer, H.-J., Pertot, I., Tamm, L., 2011. Are there alternatives to copper for controlling grapevine downy mildew in organic viticulture? Crop Prot. 30, 776-788.

Davy, A., Claverie, M., Codis, S., Bernard, F.M., Colombier, L., Davidou, L., Girard, M. Mornet, L., Perraud, J.P., Rives, C., Vergnes, D., 2010. Trials results of the Optidose » method using an adjustement of the pesticide dose for control of downy and powdery mildew. Proceedings of the 6th International Workshop on Grapevine Downy and Powdery Mildew. Bordeaux, 4-9 July, 2010.

De Escudero, I.R., Estela, A., Escriche, B., Caballero, P., 2007. Potential of the Bacillus thuringiensis toxin reservoir for the control of Lobesia botrana (Lepidoptera: tortricidae), a major pest of grape plants. Appl. Environ. Microbiol. 73, 337-340.

De Wolf, E.D., Isard, S.A., 2007. Disease cycle approach to plant disease prediction. Annu. Rev. Phytopathol 45, 203-222.

Delmotte, F., Mestre, P., Schneider, C., Kassemeyer, H.H., Kozma, P., RichartCervera, S., Rouxel, M., Delière, L., 2014. Rapid and multiregional adaptation to host partial resistance in a plant pathogenic oomycete: evidence from European populations of Plasmopara viticola, the causal agent of grapevine downy mildew. Infect. Genet. Evol, 27, 500-508.

Desneux, N., Decourtrye, A., Delpuech, J.M., 2007. The sublethal effects of pesticides on beneficial arthropods. Annu. Rev. Entomol. 52, 81-106.

Di Marco, S., Fabio, O., Calzarano, F., Roberti, R., Veronesi, A., Amalfitano, C., 2011a. Effects of grapevine applications of fosetyl-aluminium formulations for downy mildew control on "esca" and associated fungi. Phytopathol. Mediterr. 50, $285-299$.

Di Marco, S., Osti, F., Mugnai, L., 2011b. First studies on the potential of a coppe formulation for the control of leaf stripe disease within esca complex in grapevine. Phytopathol. Mediterr. 50, 300-309.

Duan, D., Fischer, S., Merz, P.R., Bogs, J., Riemann, M., Nick, P., 2016. An ancestra allele of grapevine transcription factor MYB14 promotes plant defence. J. Exp. Bot. 67, 1795-1804.

Duso, C., Vettorazzo, E., 1999. Mite population dynamics on different grape varieties with or without phytoseiids released (Acari: Phytoseiidae). Exp. Appl. Acarol. 23, 741-763.

Duso, C., Ahmad, S., Tirello, P., Pozzebon, A., Klaric, V., Baldessari, M., Malagnini, V. Angeli, G., 2014. - the impact of insecticides applied in apple orchards on the predatory mite Kampimodromus aberrans (Acari Phytoseiidae). Exp. Appl. Acarol. 62, 391-414

Duso, C., Camporese, P., Van der Geest, L.P.S., 1992. Toxicity of a number of pesticides to strains of Typhlodromus pyri and Amblyseius andersoni (Acari: Phytoseiidae). Entomophaga 37, 363-372.

Duso, C., Pozzebon, A., Capuzzo, C., Bisol, P.M., Otto, S., 2003. Grape downy mildew spread and mite seasonal abundance in vineyards: evidence for the predatory mites Amblyseius andersoni and Typhlodromus pyri. Biol. Control 27, 229-241.

Duso, C., Pozzebon, A., Kreiter, S., Tixier, M.S., Candolfi, M.P., 2012. Management of phytophagous mites in European vineyards. In: Bostanian, N.J., Vincent, C., Isaacs, R. (Eds.), “Arthropod Management in Vineyards: Pests, Approaches, and Future Directions". Springer, pp. 191-217.

Ellison, P., Ash, G., McDonald, C., 1998. An expert system for the management of Botrytis cinerea in australian vineyards. I. Dev. Agric. Syst. 56, 185-207.

Elmer, P.A.G., Reglinski, T., 2006. Biosuppression of Botrytis cinerea in grapes. Plant Pathol. 55, 155-177.

El-Wakeil, N.E., Farghaly, H.T., Ragab, Z.A., 2010. Efficacy of inundative releases of Trichogramma evanescens in controlling Lobesia botrana in vineyards in Egypt. J. Pest Sci. 83, 379, 379.

Eriksson, A., Lucchi, A., Anfora, G., Lanzo, F., Virant-Doberlet, M., Mazzoni, V., 2012. Exploitation of insect vibrational signals reveals a new method of pest management. PLoS One 7 (3), e32954. http://dx.doi.org/10.1371/ journal.pone.0100029.

Fantke, P., Friedrich, R., Jolliet, O., 2012. Health impact and damage cost assessment of pesticides in Europe. Environ. Int. 49, 9-17.

Feechan, A., Anderson, C., Torregrosa, L., Jermakow, A., Mestre, P., WiedemannMerdinoglu, S., Merdinoglu, D., Walker, A.R., Cadle-Davidson, L., Reisch, B. Aubourg, S., Bentahar, N., Shrestha, B., Bouquet, A., Adam-Blondon, A.F., Thomas, M.R., Dry, J.B., 2013. Genetic dissection of a TIR-NB-LRR locus from the wild North American grapevine species Muscadinia rotundifolia identifies paralogous genes conferring resistance to major fungal and oomycete pathogens in cultivated grapevine. Plant J. 76, 661-674.

Ferrero, A., Usowicz, B., Lipiec, J., 2005. Effects of tractor traffic on spatial variability of soil strength and water content in grass covered and cultivated sloping vineyard. Soil Tillage Res. 84, 127-138.

Fontaine, F., Pinto, C., Vallet, J., Clément, C., Gomes, A.C., Spagnolo, A., 2016. The effects of grapevine trunk diseases (GTDs) on vine physiology. Eur. J. Plant Pathol 144, 707-721.

Fourie, P.H., Halleen, F., 2006. Chemical and biological protection of grapevine propagation material from trunk disease pathogens. Eur. J. Plant Pathol 116, $255-265$.

Gadoury, D.M., Cadle-Davidson, L., Wilcox, W.F., Dry, I.B., Seem, R.C., Milgroom, M.G., 2012. Grapevine powdery mildew (Erysiphe necator): a fascinating system for the study of the biology, ecology and epidemiology of an obligate biotroph. Mol. Plant Pathol. 13, 1-16.

Gadoury, D.M., Pearson, R.C., 1990. Ascocarp dehiscence and ascospore discharge by Uncinula necator. Phytopathology 80, 393-401.

Gadoury, D.M., Seem, R.C., Ficke, A., Wilcox, W.F., 2003. Ontogenic resistance to powdery mildew in grape berries. Phytopathology 93, 547-555.

Gaudin, R., Celette, F., Gary, C., 2010. Contribution of runoff to incomplete off season soil water refilling in a Mediterranean vineyard. Agric. Water Manag. 97, 1534-1540.

Genini, M., 2000. Antagonistes de la cicadelle verte et des vers de la grappe dans le vignoble Valaisan et les milieux environnants. Rev. Suisse Viticultue Arboric. Hortic. 32, 153-160.

Gessler, C., Rumbou, A., Gobbin, D., Loskill, B., Pertot, I., Raynal, M., Jermini, M., 2003. A change in our conception of the life cycle of Plasmopara viticola: oosporic infections versus asexual reproduction in epidemics. Bull. IOBC/wprs 26, 13-16.

Gil, E., Llorens, J., Landers, A., Llop, J., Giralt, L., 2011. Field validation of Dosavinã, a decision support system to determine the optimal volume rate for pesticide application in vineyards. Eur. J. Agron. 35, 33-46.

Gilligan, T.M., Epstein, M.E., Passoa, S.C., Powell, J.A., Sage, O.C., Brown, J.W., 2011. Discovery of Lobesia botrana ([Denis \& Schiffermüller]) in California: an invasive species new to North America (Lepidoptera: Tortricidae). Proceedings of the Entomological Society of Washington 113, 14-30.

Gimenez, C., Cabrera, R., Reina, M., Gonzalez-Coloma, A., 2007. Fungal endophytes and their role in plant protection. Curr. Org. Chem. 11, 707-720.

Gindro, K., Alonso-Villaverde, V., Voinesco, F., Spring, J.L., Viret, O., Dubuis, P.H., 2012. Susceptibility to downy mildew in grape clusters: new microscopical and biochemical insights. Plant Physiol Biochem. 52, 140-146.

Gobbin, D., Rumbou, A., Linde, C.C., Gessler, C., 2006. Population genetic structure of Plasmopara viticola after 125 years of colonization in European vineyards. Mol. Plant Pathol. 7, 519-531.

Gonzalez, E., Caffi, T., Ciliberti, N., Rossi, V., 2015. A Mechanistic model of Botrytis cinerea on grapevine that includes weather, vine growth stage, and the main infection pathways. PLOS One. http://dx.doi.org/10.1371/journal.pone.0140444.

Gramaje, D., Armengol, J., 2011. Fungal trunk pathogens in the grapevine propagation process: potential inoculum sources, detection, identification, and management strategies. Plant Dis. 95, 1040-1055.

Gramaje, D., Di Marco, S., 2015. Identifying practices likely to have impacts on grapevine trunk disease infections: a European nursery survey. Phytopathol. Mediterr. 54, 313.

Guan, J., Nutter, F.W., 2003. Quantifying the interarater repeatability and interrater reliability of visual and remote-sensing disease-assessment methods in the alfalfa foliar pathosystem. Can. J. Plant Pathol 25, 143-149.

Gubler, W.D., Marois, J.J., Bledsoe, A.M., Bettiga, L.J., 1987. Control of botrytis bunch rot of grape with canopy management. Plant Dis. 71, 599-601.

Hardoim, P.R., van Overbeek, L.S., Berg, G., Pirttilä, A.M., Compant, S., Campisano, A., 
Döring, M., Sessitsch, A., 2015. The hidden world within plants: ecological and evolutionary considerations for defining functioning of microbial endophytes. Microbiol. Mol. Biol. Rev. 79 (28), 293-320.

Hill, G.K., 1990. Plasmopara Risk Oppenheim - a deterministic computer model for the viticultural extension service. Not. sulle Mal. delle Piante 111, 231, 223.

Hommay, G., Gertz, C., Kienlen, J.C., Pizzol, J., Chavigny, P., 2002. Comparison between the control efficacy of Trichogramma evanescens westwood (hymenoptera: trichogrammatidae) and two Trichogramma cacoeciae. Biocontrol Sci. Technol. 12, 569-581.

Ifoulis, A.A., Savopoulou-Soultani, M., 2004. Biological control of Lobesia botrana (Lepidoptera : tortricidae) larvae by using different formulations of Bacillus thuringiensis in 11 vine cultivars under field conditions. J. Econ. Eeconomic Entomol 97, 340-343.

Ioriatti, C., Anfora, G., Tasin, M., De Cristofaro, A., Witzgall, P., Lucchi, A., 2011. Chemical ecology and management of Lobesia botrana (Lepidoptera: tortricidae). J. Econ. Entomol 104, 1125-1137.

Ioriatti, C., Bagnoli, B., Lucchi, A., Veronelli, V., 2004. Vine moths control by mating disruption in Italy: results and future prospects. Redia 87, 117-128.

Ioriatti, C., Lucchi, A., 2016. Semiochemical strategies for tortricid moth control in apple orchards and vineyards in Italy. J. Chem. Ecol. 42, 571-583.

Irigaray, F.J.S.D.C., Moreno-Grijalba, F., Marco, V., Perez-Moreno, I., 2010. Acute and reproductive effects of Align ( $R$ ), an insecticide containing azadirachtin, on the grape berry moth, Lobesia botrana. J. Insect Sci. 10, 1-33.

Iriti, M., Vitalini, S., Di Tommaso, G., D'Amico, S., Borgo, M., Faoro, F., 2011. New chitosan formulation prevents grapevine powdery mildew infection and improves polyphenol content and free radical scavenging activity of grape and wine. Aust. J Grape Wine Res, 17, 263-269.

Jacometti, M.A., Wratten, S.D., Walter, M., 2010. Review: alternatives to synthetic fungicides for Botrytis cinerea management in vineyards. Aust. J. Grape Wine Res. 16, 154-172.

Karabelas, A.J., Plakas, K.V., Solomou, E.S., Drossou, V., Sarigiannis, D.A., 2009. Impact of European legislation on marketed pesticides - a view from the standpoint of health impact assessment studies. Environ. Int. 35, 1096-1107.

Kast, W.K., 1997. A step by step risk analysis (SRA) used for planning sprays against powdery mildew (OiDiag-System). Viticolture Enological Sci. 52, 230-321.

Kast, W.K., Bleyer, K., 2010. The expert system OiDiag2.2-a useful tool for the precise scheduling of sprays against the powdery mildew of vine (Erysiphe necator Schwein). Proceedings of the 6th International Workshop on Grapevine Downy and Powdery Mildew. Bordeaux, 4-9 July, 2010.

Kuflik, T., Prodorutti, D., Frizzi, A., Gafni, Y., Simon, S., Pertot, I., 2009. Optimization of copper treatment in viticulture by using a web-based decision support system. Comput. Electron. Agric. 68, 36-43.

Lacombe, T., Audeguin, L., Boselli, M., Bucchetti, B., Cabello, F., Chatelet, P., Crespan, M., D'Onofrio, C., Eiras Dias, J., Ercisli, S., Gardiman, M., Grando, M.S. Imazio, S., Jandurova, O., Jung, A., Kiss, E., Kozma, P., Maul, E., Maghradze, D., Martinez, M.C., Muñoz, G., Pátková, J.K., Pejic, I., Peterlunger, E., Pitsoli, D., Preiner, D., Raimondi, S., Regner, F., Szoke, G., Savin, S., Savvides, A., Schneider, J.L., Spring, A., Veres, A., Boursiquot, J.M., Bacilieri, R., This, P., 2011 Grapevine European catalogue: towards a comprehensive list. Vitis 50, 65-68.

Lamichhane, J.R., Dachbrodt-Saaydeh, S., Kudsk, P., Messéan, A., 2015. Toward a reduced reliance on conventional pesticides in European agriculture. Plant Dis. $100,10-24$.

Lamichhane, J.R., Bischoff-Schaefer, M., Bluemel, S., Dachbrodt-Saaydeh, S., Dreux, L., Jansen, J.-P., Kiss, J., Köhl, J., Kudsk, P., Malausa, T., Messéan, A Nicot, P.C., Ricci, P., Thibierge, J., Villeneuve, F., 2016. Identifying obstacles and ranking common biological control research priorities for Europe to manage most economically important pests in arable, vegetable and perennial crops. Pest Manag. Sci. http://dx.doi.org/10.1002/ps.4423.

Lamichhane, J.R., Venturi, V., 2015. Synergisms between microbial pathogens in plant disease complexes: a growing trend. Front. Plant Sci. 6, 385.

Lapchin, L., Shtienberg, D., 2002. Sampling and monitoring pests and diseases. In: Albajes, R., Gullino, M.L., Van Lenteren, J.C., Elad, Y. (Eds.), Integrated Pest and Disease Management in Greenhouse Crops. Kluwer academic publishers, Dordrecht, pp. 82-96.

Lecomte, P., Darrieutort, G., Liminana, J.M., Comont, G., Muruamendiaraz, A. Legorburu, F.J., Fermaud, M., 2012. New insights into esca of grapevine: the development of foliar symptoms and their association with xylem discoloration. Plant Dis. 96, 924-934.

Legler, S.E., Caffi, T., Rossi, V., 2011. A nonlinear model for temperature-dependent development of Erysiphe necator chasmothecia on grapevine leaves. Plant Pathol. 61, 96-105.

Legler, S.E., Caffi, T., Rossi, V., Giosuè, S., 2010. Modelling the life cycle of Erysiphe necator. Proceedings of the 6th International Workshop on Grapevine Downy and Powdery Mildew. Bordeaux, 4-9 July, 2010.

Liguori, M., Guidi, S., 1995. Influence of different constant humidities and temperatures on eggs and larvae of a strain of Typhlodromus exhilaratus Ragusa (Acari Phytoseiidae). Redia 78, 321-329.

Maanen, A.V., Xu, X., 2003. Modelling plant disease epidemics. Eur. J. Plant Pathol 109, 669-682.

Madden, L.V., Hughes, G., Ellis, M.A., 1995. Spatial heterogeneity of the incidence of grape downy mildew. Phytopathology 85, 269-275.

Magarey, R.D., Travis, J.W., Russo, J.M., Seem, R.C., Magarey, P.A., 2002. Decision support systems: quenching the thirst. Plant Dis. 86, 4-14.

Magnien, C., Jacquin, D., Muckensturm, N., Guillemard, P., 1991. MILVIT: a descriptive quantitative model for the asexual phase of grapevine downy mildew. Bull.
IOBC/wprs 21, 451-459

Marchesini, E., Dalla Montà, L., 1994. Observations on natural enemies of Lobesia botrana in Venetian vineyards. Boll. Zool. Agrar. Bachic. 26, 201-230.

Massart, S., Perazzolli, M., Hofte, M., Pertot, I., Jijakli, M.H., 2015. Impact of the omic technologies for understanding the modes of action of biological control agents against plant pathogens. BioControl 60, 725-746.

Mazzoni, V., Lucchi, A., Cokl, A., Prešern, J., Virant-Doberlet, M., 2009a. Disruption o the reproductive behaviour of Scapho,ideus titanus by playback of vibrational signals. Entomologia Exp. Appl. 133, 174-185.

Mazzoni, V., Prešern, J., Lucchi, A., Virant-Doberlet, M., 2009b. Reproductive strategy of the nearctic leafhopper Scaphoideus titanus ball (Hemiptera: cicadellidae) Bull. Entomol Res. 99, 401-413.

McMurtry, J.A., Huffaker, C.B., van de Vrie, M., 1970. I. Tetranychid enemies: their biological characters and the impact of spray practices. Hilgardia 40, 331-390.

Meyhofer, R., Casas, J., 1999. Vibratory stimuli in host location by parasitic wasps. J. Insect Physiol 45, 967-971.

Migicovsky, Z., Sawler, J., Money, D., Eibach, R., Miller, A.J., Luby, J.J., Jamieson, A.R. Velasco, D., von Kintzel, S., Warner, J., Wührer, W., Brown, P.J., Myles, S., 2016. Genomic ancestry estimation quantifies use of wild species in grape breeding. BMC Genomics 17, 478.

Moreau, J., Villemant, C., Benrey, B., Thiéry, D., 2010. - Species diversity and composition of larval parasitoids of the European grapevine moth (Lobesia botrana): the influence of region and cultivar. Biol. control 54, 300-306.

Morlat, R., Jacquet, A., 2003. Grapevine root system and soil characteristics in a vineyard maintained long-term with or without interrow sward. Am. J. Enol Vitic. 54, 1-7.

Mugnai, L., Graniti, A., Surico, G., 1999. Esca (black measles) and brown woodstreaking: two old and elusive diseases of grapevines. Plant Dis. 83, 404-418.

Nair, N.G., Allen, R.N., 1993. Infection of grape flowers and berries by Botrytis cinered as a function of time and temperature. Mycol. Res. 97, 1012-1014.

Naud, O., Delière, L., Cartolaro, P., Léger, B., 2010. Testing a decision system for integrated protection against mildews - the wine-grower, the adviser and the computer model. Proceedings of the 6th International Workshop on Grapevine Downy and Powdery Mildew. Bordeaux, 4-9 July 2010.

Nelson, K.E., 1956. The effect of Botrytis infection on the tissue of Tokay grapes Phytopathology 46, 223-229.

Nita, M., Ellis, M.A., Wilson, L.L., Madden, L.V., 2006. Effects of application of fungicide during the dormant period on phomopsis cane and leaf spot of grape disease intensity and inoculum production. Plant Dis. 90, 1195-1200.

Oliva, J., Navarro, S., Navarro, G., Camara, M.A., Barba, A., 1999. Integrated control of grape berry moth (Lobesia botrana), powdery mildew (Uncinula necator), downy mildew (Plasmopara viticola) and grapevine sour rot (Acetobacter spp.). Crop Prot. 18, 581-587.

Orlandini, S., Gozzini, B., Rosa, M., Egger, E., Storchi, P., Maracchi, G., Miglietta, F. 1993. PLASMO: a simulation model for control of Plasmopara viticola on grapevine. Bull. IOBCwprs 23, 619-626.

Paillot, A., 1917. Observations et experiences sur les champignons parasites des insects. Ann. Epiphyt. 7, 329-334.

Pancher, M., Ceol, M., Corneo, P.E., Longa, C.M.O., Yousaf, S., Pertot, I., Campisano, A. 2012. Fungal endophytic communities in grapevines (Vitis vinifera 1.) respond to crop management. Appl. Environ. Microbiol. 78, 4308-4317.

Park, E.W., Seem, R.C., Gadoury, D.M., Pearson, R.C., 1997. DMCAST: a prediction model for grape downy mildew development. Vitic. Enological Sci. 52, 182-189.

Pease, C.E., Lopez-Olguin, J.F., Perez-Moreno, I., Marco-Mancebon, V., 2016. Effects of kaolin on Lobesia botrana (Lepidoptera: tortricidae) and its compatibility with the natural enemy, Trichogramma cacoeciae ( Hymenoptera: trichogrammatidae). J. Econ. Entomol 109, 740-745.

Pedneault, K., Provost, C., 2016. Fungus resistant grape varieties as a suitable alternative for organic wine production: benefits, limits, and challenges. Sci. Hortic. http://dx.doi.org/10.1016/j.scienta.2016.03.016.

Peressotti, E., Wiedemann-Merdinoglu, S., Delmotte, F., Bellin, D., Gaspero, G.D. Testolin, R., Merdinoglu, D., Mestre, P., 2010. Breakdown of resistance to grapevine downy mildew upon limited deployment of a resistant variety. BMC Plant Biol. 10, 147. http://dx.doi.org/10.1186/1471-2229-10-147.

Pertot, I. Gobbin, D. De Luca, F, Prodorutti, D, 2008. Methods of assessing the incidence of Armillaria root rot across viticultural areas and the pathogen's genetic diversity and spatial-temporal pattern in northern Italy. Crop Prot. 27, 1061-1070.

Pertot, I., Prodorutti, D., Colombini, A., Pasini, L., 2016. Trichoderma atroviride SC1 prevents Phaeomoniella chlamydospora and Phaeoacremonium aleophilum infection of grapevine plants during the grafting process in nurseries. Biocontrol 61, 257-267.

Pessina, S., Lenzi, L., Perazzolli, M., Campa, M., Dalla Costa, L., Urso, S., Valè, G., Salamini, F., Velasco, R., Malnoy, M., 2016. Knockdown of MLO genes reduces susceptibility to powdery mildew in grapevine. Hortic. Res. 3, 16016. http:/ dx.doi.org/10.1038/hortres.2016.16.

Pierron, R.J., Pages, M., Couderc, C., Compant, S., Jacques, A., Violleau, F., 2015 In vitro and in planta fungicide properties of ozonated water against the escaassociated fungus Phaeoacremonium aleophilum. Sci. Hortic. 189, 184-191.

Pinto, C., Pinho, D., Sousa, S., Pinheiro, M., Egas, C., Gomes, A.C., 2014. Unravelling the diversity of grapevine microbiome. Plos One 9, e85622.

Polajnar, J., Eriksson, A., Lucchi, A., Anfora, G., Virant-Doberlet, M., Mazzoni, V., 2015 Manipulating behaviour with substrate-borne vibrations - potential for insect pest control. Pest Manag. Sci. 71, 15-23.

Polge de Combret-Champart, L., Guilpart, N., Mérot, A., Capillon, A., Gary, C., 2013. 
Determinants of the degradation of soil structure in vineyards with a view to conversion to organic farming. Soil use Manag. 29, 557-566.

Pozzebon, A., Duso, C., 2008. Grape downy mildew Plasmopara viticola, an alternative food for generalist predatory mites occurring in vineyards. Biol. Contro $45,441-449$.

Rapp, A., Knipser, W., Engel, L., Ullemeyer, H., Heimann, W., 1980. Off-flavour compounds in the berry and wine aroma of grapevine hybrids. I. The strawberry-like flavour. Vitis 19, 13-23.

Raynal, M., Debord, C., Guittard, S., Vergnes, M., 2010. EPIcure, a geographic information decision support system risk assessment of downy and powdery mildew epidemics in Bordeaux vineyards. Proceedings of the 6th International Workshop on Grapevine Downy and Powdery Mildew. Bordeaux, 4-9 July, 2010.

Reineke, A., Thiéry, D., 2016. Grapevine insect pests and their natural enemies in the age of global warming. J. Pest Sci. 89, 313-328.

Reiss, K., Zinkernagel, V., 1997. Epidemiologische Untersuchungen zur Ascosporenfreisetzung von Pseudopezicula tracheiphila (Müll.-Thurg.) Korf \& Zhuang, dem Erreger des Roten Brenners am Wein. Z. für Pflanzenkrankh. Pflanzenschutz 104, 113-125.

Ripoche, A., Rellier, J.P., Martin-Clouaire, R., Paré, N., Biarnès, A., Gary, C., 2011 Modelling adaptive management of intercropping in vineyards to satisfy agronomic and environmental performances under Mediterranean climate. Environ. Model. Softw. 26, 1467-1480.

Rodriguez-Rajo, F.J., Jato, V., Fernandez-Gonzalez, M., Aira, M.J., 2010. The use of aerobiological methods for forecasting Botrytis spore concentrations in a vineyard. Grana 49, 56-65.

Rolshausen, P.E., Úrbez-Torres, J.R., Rooney-Latham, S., Eskalen, A., Smith, R.J. Gubler, W.D., 2010. Evaluation of pruning wound susceptibility and protection against fungi associated with grapevine trunk diseases. Am. J. Enol Vitic. 61, 113-119.

Rossi, V., Caffi, T., 2012. The role of rain in dispersal of the primary inoculum of Plasmopara viticola. Phytopathology 102, 158-165.

Rossi, V., Caffi, T., Giosuè, S., Bugiani, R., 2008. A mechanistic model simulating primary infections of downy mildew in grapevine. Ecol. Model. 212, 480-491.

Rossi, V., Caffi, T. Gobbin, D. 2013. Contribution of molecular studies to botanical epidemiology and disease modelling: grapevine downy mildew as a case-study. Eur. J. Plant Pathol 135, 641-654.

Rossi, V., Caffi, T., Salinari, F., 2012. Helping farmers face the increasing complexity of decision-making for crop protection. Phytopathol. Mediterr. 51, 457-479.

Rossi, V., Giosuè, S., Caffi, T., 2009. Modelling the dynamics of infections caused by sexual and asexual spores during Plasmopara viticola epidemics. J. Plant Patho 91, 615-627.

Rossi, V., Giosué, S., Caffi, T., 2010. Modelling plant diseases for decision making in crop protection. In: Oerke, E.C. (Ed.), Precision Crop Protection - the Challenge and Use of Heterogeneity. Springer Science, Dordrecht (NL).

Rossi, V., Salinari, F., Poni, S., Caffi, T., Bettati, T., 2014. Addressing the implementation problem in agricultural decision support systems: the example of vite.net ${ }^{\circledR}$. Comput. Electron. Agric. 100, 88-99.

Rusch, A., Binet, D., Delbac, L., Thiéry, D., 2016a. Local and landscape effects of agricultural intensification on carabid community structure and weed seed predation in a perennial cropping system. Landsc. Ecol. http://dx.doi.org/ 10.1007/s10980-016-0390-x.

Rusch, A., Delbac, L., Muneret, L., Thiéry, D., 2015. Organic farming and moth density affect parasitism rates of tortricid moths in vineyards. Agric. Ecosyst. Environ. $214,46-53$.

Rusch, A., Sentenac, G., Thiéry, D., 2016b. Biodiversité fonctionnelle en viticulture et services de régulation naturelle des ravageurs : quels leviers d'action. In: Deguine, J.P., Gloanec, C., Laurent, P., Ratnadas, A., Aubertot, J.N. (Eds.), Protec tion agroécologique des cultures. Quae.com, pp. 162-166.

Sall, M.A., 1980. Epidemiology of grape powdery mildew: a model. Phytopathology $70,338-342$

Sanders, C.J., 1997. Mechanism of mating disruption in moth. In: new directions, Cardé, R.T., Minks, A.K. (Eds.), Insect Pheromone Research. Internationa Thomson Publishing, pp. 333-346.

Savary, S., Delbac, L., Rochas, A., Taisant, G., Willocquet, L., 2009. Analysis of nonlinear relationships in dual epidemics, and its application to the management of grapevine downy and powdery mildews. Phytopathology 99, 930-942.

Seem, R.C., 1984. Disease incidence and severity relationships. Annu. Rev. Phytopathol 22, 133-150.

Seem, R.C., Magarey, P.A., McCloud, P.I., Wachtel, M.F., 1985. A sampling procedure to detect grapevine downy mildew. Phytopathology 75, 1252-1257.

Shahini, S., Kullaj, E., Cakalli, A., Cakalli, M., Lazarevska, S., Pfeiffer, D.G., Gumeni, F. 2010. Population dynamics and biological control of European grapevine moth (Lobesia botrana: Lepidoptera: tortricidae) in Albania using different strains of Bacillus thuringiensis. Int. J. Pest Manag. 56, 281-286.

Siegfried, W., Viret, O., Huber, B., Wohlhauser, R., 2007. Dosage of plant protection products adapted to leaf area index in viticulture. Crop Prot. 26, 73-82.

Smart, R., 2015. Trunk diseases: timely trunk renewal to overcome trunk disease. Wine Vitic. J. 30, 44

Sosnowski, M.R., Wicks, T.J., Scott, E.S., 2011. Control of Eutypa dieback in grapevines using remedial surgery. Phytopathol. Mediterr. 50, 277-284.

Surico, G., Bandinelli, R., Braccini, P., Di Marco, S., Marchi, G., Mugnai, L., Parrini, C.
2004. On the factors that may have influenced the esca epidemic in the eighties in Tuscany. Phytopathol. Mediterr. 43, 136-143.

Thiéry, D., 2011. Gaps in knowledge for modern integrated protection in viticulture: lessons from controlling grape berry moths. Bull. IOBC/wprs 67, 305-311.

Thiéry, D., Xuéreb, A., Villemant, C., Sentenac, G., Delbac, L., Kuntzman, P., 2001. Les parasites de tordeuses de vignobles : aperç de quelques espèces présentes dans 3 régions viticoles françaises. Bull. IOBC/wprs 24, 135-141.

Thomas, C.S., Gubler, W.D., Leavitt, G., 1994. Field testing of a powdery mildew disease forecast model on grapes in California. Phytopathology 84, 1070.

Tixier, M.-S., Baldassar, A., Duso, C., Kreiter, S., 2013. - Phytoseiidae in European grape (Vitis vinifera L.): bio-ecological aspects and keys to species (Acari: mesostigmata). Zootaxa 3721, 101-142.

Tixier, M.S., Kreiter, S., Croft, B.A., Auger, P., 2002. Colonization of vineyards by Kampimodromus aberrans (Oudemans) (Acari: Phytoseiidae): dispersal from surrounding plants as indicated by random amplified polymorphism DNA typing. Agric. For. Entomol 4, 255-264.

Töpfer, R., Hausmann, L., Harst, M., Maul, E., Zyprian, E., Eibach, R., 2011. New horizons for grapevine breeding. In: Flachowsky, H., Hanke, M.V. (Eds.), Methods in Temperate Fruit Breeding. Global Science Books, pp. 79-100.

Tran Manh Sung, C. Strizyk, C., Clerjeau, M., 1990. Simulation of the date of maturity of Plasmopara viticola oospores to predict the severity of primary infections in grapevine. Plant Dis. 74, 120-124.

Valdés-Gómez, H., Fermaud, M., Roudet, J., Calonnec, A., Gary, C., 2008. Grey mould incidence is reduced on grapevines with lower vegetative and reproductive growth. Crop Prot. 27, 1174-1186.

Valdés-Gómez, H., Gary, C., Cartolaro, P., Lolas-Caneo, M., Calonnec, A., 2011. Powdery mildew development is positively influenced by grapevine vegetative growth induced by different soil management strategies. Crop Prot. 30, $1168-1177$.

van Aubel, G., Buonatesta, R., Van Cutsem, P., 2014. COS-OGA: a novel oligosaccharidic elicitor that protects grapes and cucumbers against powdery mildew. Crop Prot. 65, 129-137.

Vassiliou, V.A., 2011. Effectiveness of insecticides in controlling the first and second generations of the Lobesia botrana (Lepidoptera: tortricidae) in table grapes. J. Econ. Entomol 104, 580-585.

Vega, F.E., Goettel, M.S., Blackwell, M., Chandler, D., Jackson, M.A., Keller, S., Koike, M., Maniania, N.K., Monzon, A., Ownley, B.H., Pell, J.K., Rangel, D.E.N., Roy, H.E., 2009. Fungal entomopathogens: new insights on their ecology. Fungal Ecol. 2, 149-159.

Vera, J., Castro, J., Gonzalez, A., Moenne, A., 2011. Seaweed polysaccharides and derived oligosaccharides stimulate defense responses and protection against pathogens in plants. Mar. Drugs 9, 2514-2525.

Vercesi, A., Zerbetto, F., Rho, G., 1999. Impiego dei modelli EPI e PRO nella difesa antiperonosporica del vigneto. Frustula entomol. 22, 92-97.

Vincent, C., Isaacs, R., Bostanian, N.J., Lasnier, J., 2012. Principles of arthropod pest management in vineyards. In: Bostanian, N.J., Vincent, C., Isaacs, R. (Eds.), Arthropod Management in Vineyards: Pests, Approaches and Future Directions. Springer Science \& Business Media, pp. 1-15.

Virant-Doberlet, M., King, R.A., Polajnar, J., Symondson, W.O.C., 2011. Molecular diagnostics reveal spiders that exploit prey vibrational signals used in sexual communication. Mol. Ecol. 20, 2204-2216.

Viret, O., Dubuis, P.H., Frabre, A.L., Bloesch, B., Siegfried, W., Naef, A., Huber, M., Bleyer, G., Kassemeyer, H.H., Breuer, M., Krause, R., 2011. www.agrometeo.ch an interactive platform for a better management for grapevine diseases and pests. Bull. IOBC/wprs 67, 85-91.

Vogelweith, F., Moreau, J., Thiéry, D., Moret, Y., 2015. Food-mediated modulation of immunity in a phytophagous insect: an effect of nutrition rather than parasitic contamination. J. Insect Physiol 77, 55-61.

Vogelweith, F., Moret, Y., Monceau, K., Thiéry, D., Moreau, J., 2016. The relative abundance of hemocyte types in a polyphagous moth larva depends on diet. J. Insect Physiol 88, 33-39.

Voltz, M., Louchart, X., Andrieux, P. Lennartz, B, 2003. Processes of pesticide dissipation and water transport in a Mediterranean farmed catchment. Int. Assoc. Hydrological Sci. 278, 422-428.

Wäckers, F.L., Van Rijn, P., Bruin, J., 2005. Plant-provided Food for Carnivorous Insects: a Protective Mutualism and its Applications. Cambridge University Press, Cambridge, UK.

Waite, H., Whitelaw-Weckert, M., Torley, P., 2015. Grapevine propagation: principles and methods for the production of high-quality grapevine planting material. N. Z. J. Crop Hortic. Sci. 43, 144-161.

Walton, V.M., Daane, K.M., Bentley, W.J., Millar, J.G., Larsen, T.E., Malakar-kuenen, R., 2006. Pheromone-based mating disruption of Planococcus ficus (Hemiptera: pseudococcidae) in California vineyards. J. Econ. Entomol 99, 1280-1290.

Xuéreb, A., Thiéry, D., 2006. Does natural larval parasitism of Lobesia botrana vary between years, generation, density of the host and vine cultivar? Bull. Entomol Res. 96, 105-110.

Zanzotto, A., Morroni, M., 2016. Major biocontrol studies and measures against fungal and oomycete pathogens of grapevine. In: Compant, S., Mathieu, F. (Eds.), Biocontrol of Major Grapevine Diseases: Leading Research. CABI, Oxford, UK, pp. 1-34. 